\title{
Immature Neurons and Radial Glia, But Not Astrocytes or Microglia, Are Altered in Adult Cntnap2 and Shank3 Mice, Models of Autism
}

\author{
Elise C. Cope,, ${ }^{1,2}$ Brandy A. Briones, ${ }^{1,2, *}$ Bd Adam T. Brockett, ${ }^{1,2, *}$ Susana Martinez,, ${ }^{1,2}$ Pierre-Antoine \\ Vigneron, ${ }^{1,2}$ () Maya Opendak, ${ }^{1}$ (D) Samuel S.-H. Wang, ${ }^{1,3}$ and Elizabeth Gould ${ }^{1,2}$
}

DOI:http://dx.doi.org/10.1523/ENEURO.0196-16.2016

${ }^{1}$ Princeton Neuroscience Institute, Princeton University, Princeton, New Jersey 08540, ${ }^{2}$ Department of Psychology, Princeton University, Princeton, New Jersey 08544, and ${ }^{3}$ Department of Molecular Biology, Princeton University, Princeton, New Jersey 08544

\begin{abstract}
Autism spectrum disorder (ASD) is often associated with cognitive deficits and excessive anxiety. Neuroimaging studies have shown atypical structure and neural connectivity in the hippocampus, medial prefrontal cortex (mPFC), and striatum, regions associated with cognitive function and anxiety regulation. Adult hippocampal neurogenesis is involved in many behaviors that are disrupted in ASD, including cognition, anxiety, and social behaviors. Additionally, glial cells, such as astrocytes and microglia, are important for modulating neural connectivity during development, and glial dysfunction has been hypothesized to be a key contributor to the development of ASD. Cells with astroglial characteristics are known to serve as progenitor cells in the developing and adult brain. Here, we examined adult neurogenesis in the hippocampus, as well as astroglia and microglia in the hippocampus, mPFC, and striatum of two models that display autism-like phenotypes, Cntnap $2^{-1-}$ and Shank $3^{+/ \Delta C}$ transgenic mice. We found a substantial decrease in the number of immature neurons and radial glial progenitor cells in the ventral hippocampus of both transgenic models compared with wild-type controls. No consistent differences were detected in the number or size of astrocytes or microglia in any other brain region examined. Future work is needed to explore the functional contribution of adult neurogenesis to autism-related behaviors as well as to temporally characterize glial plasticity as it is associated with ASD.
\end{abstract}

Key words: astrocytes; autism; microglia; neurogenesis; radial glia

\section{Significance Statement}

ASD is a heterogeneous developmental condition that is estimated to affect 1 in 68 children under 8 years of age in the United States. Postmortem studies suggest that both neurons and glia may be compromised in ASD, but few studies have explored neural and glial plasticity across relevant mouse models. We found a decrease in adult neurogenesis in the ventral hippocampus, a brain region important for anxiety and stress regulation, in two autism mouse models compared with wild-type controls. However, we found no differences in markers of glial dysregulation across autism mouse models in the hippocampus, medial prefrontal cortex, or striatum, suggesting that persistent abnormalities in glia in these brain regions are not necessary for the ASD behavioral phenotype. 


\section{Introduction}

ASD is characterized by deficits in social communication, repetitive behaviors, and/or restricted interests (American Psychiatric Association, 2013), and is often associated with cognitive deficits (Goh and Peterson, 2012) and increased prevalence of anxiety disorders (Vasa and Mazurek, 2015; Russell et al., 2016). Neuroimaging and postmortem studies of ASD individuals have identified an atypical structure in a variety of brain regions, including, but not limited to, the hippocampus, the medial prefrontal cortex (mPFC), and the striatum (Schumann et al., 2004; Carper and Courchesne, 2005; Langen et al., 2009), regions implicated in the regulation of cognition, anxiety, and stereotyped behavior. Additionally, postmortem studies have revealed greater numbers of dendritic spines (Hutsler and Zhang, 2010; Penzes et al., 2011), sites of excitatory synapses, when compared with controls, potentially due to abnormal synapse elimination during prenatal and postnatal development.

ASD is a highly heritable disorder with concordance rates as high as $90 \%$ between monozygotic twins and $30 \%$ between siblings (Rosenberg et al., 2009; Geschwind, 2011; Ozonoff et al., 2011). Furthermore, studies have identified hundreds of genes associated with the disorder, many of which encode for proteins important for synaptic structure and function (Geschwind, 2011; Parikshak et al., 2013). Transgenic mice based on rare mutations offer tractable models with which to study the development of ASD, test potential treatments, as well as study changes in cell function and behavior (Lázaro and Golshani, 2015). Knockout of Cntnap2, a gene encoding for a neuronal transmembrane protein that is thought to be important for the control of neuron-glia interactions, is associated with alterations in synaptic structure, neuronal network activity, and an autism-related phenotype in mice (Peñagarikano et al., 2011; Gdalyahu et al., 2015). Shank3 mutations are linked to the development of PhelanMcDermid Syndrome (22q13 deletion syndrome), a disorder that presents with many of the core symptoms of ASD as well as global developmental delays (Jiang and Ehlers, 2013). Shank3 encodes for a scaffolding protein that is

Received July 8, 2016; accepted September 9, 2016; First published September 29, 2016.

The authors declare no competing financial interests.

Author contributions: E.C.C., B.A.B., A.T.B., S.S.-H.W., and E.G. designed research; E.C.C., B.A.B., A.T.B., S.M., P.-A.V., and M.O. performed research; S.S.-H.W. provided unpublished reagents/analytic tools; E.C.C., B.A.B., A.T.B., S.M., P.-A.V., and M.O. analyzed data; E.C.C., B.A.B., A.T.B., S.S.H.W., and E.G. wrote the paper.

This work was supported by a grant from the Nancy Lurie Marks Family Foundation.

${ }^{*}$ B.A.B. and A.T.B. contributed equally to this work.

Acknowledgments: We thank Laura Lynch for assistance with mouse breeding.

Correspondence should be addressed to Elise Cope, Department of Psychology, Princeton Neuroscience Institute, Princeton University, Princeton, NJ 08544. E-mail: ecope@princeton.edu.

DOI:http://dx.doi.org/10.1523/ENEURO.0196-16.2016

Copyright @ 2016 Cope et al.

This is an open-access article distributed under the terms of the Creative Commons Attribution 4.0 International, which permits unrestricted use, distribution and reproduction in any medium provided that the original work is properly attributed. involved in the maintenance of the postsynaptic density. Mice with partial or complete deletion of Shank3 have deficits in social interaction and cognition as well as alterations in synaptic physiology (Jiang and Ehlers, 2013; Kouser et al., 2013).

Several lines of evidence point to an important role for glial dysregulation in ASD. Prenatal maternal illness and stress, conditions that stimulate the maternal immune system and induce reactive gliosis (Zager et al., 2015), predispose offspring to develop ASD (Kinney et al., 2008; Atladóttir et al., 2010). Not only have postmortem studies shown that individuals with ASD have increased numbers of astrocytes and microglia in a variety of brain regions (Vargas et al., 2005; Morgan et al., 2010), but these studies have also revealed abnormalities in peripheral proinflammatory cytokine levels in individuals with ASD (Ashwood et al., 2011; Xu et al., 2015). While traditionally thought of as support cells, recent evidence has implicated a role for astrocytes in synapse formation (Christopherson et al., 2005; Kucukdereli et al., 2011) and elimination (Chung et al., 2013), as well as in synaptic plasticity (Henneberger et al., 2010). Microglia, the resident immune cells of the brain, are also known to sculpt neural circuits by engulfing weak synapses during development (Paolicelli et al., 2011; Schafer et al., 2012). Reactive microglia produce several inflammatory molecules that can directly impact synaptic plasticity by altering firing rates and degrading synapses (Kondo et al., 2011). Since both astrocytes and microglia are involved in shaping and modulating neural connectivity, their early disruption may contribute to abnormal brain development and an ASD phenotype.

In addition to glial plasticity, another form of plasticity, adult neurogenesis in the hippocampus, may also be altered in ASD. Reduced adult neurogenesis in the hippocampus has been reported in the BTBR mouse model of autism (Stephenson et al., 2011); however, no work has explored the possibility that this is a feature common to other ASD mouse models. Because adult neurogenesis has been linked to a variety of hippocampus-mediated behaviors, including learning and memory, anxiety regulation, as well as social behaviors (Opendak and Gould, 2015; Opendak et al., 2016), it is possible that alterations in adult neurogenesis may underlie part of the abnormal behavioral phenotype seen in autism.

To explore the possibility that genetic mouse models of ASD are associated with differences in neuronal and glial plasticity, we examined the number of new neurons and radial glia in the hippocampus, as well as the number, morphology, and reactivity of astrocytes and microglia in the hippocampus, mPFC, and striatum of Cntnap2 ${ }^{-1-}$, Shank3 ${ }^{+/ \Delta C}$, and wild-type (WT) male mice.

\section{Materials and Methods}

\section{Animals}

All animal procedures were performed in accordance with the Princeton University Institutional Animal Care and Use Committee regulations and conformed to the $\mathrm{Na}$ tional Research Council Guide for the Care and Use of Laboratory Animals (2011). Adult male C57BL/6J (catalog 
\#000664) and Cntnap2 ${ }^{-1-}$ (catalog \#017482) mice were obtained from The Jackson Laboratory. Shank $3^{+/ \Delta C}$ (catalog \#018398) mice were originally obtained from The Jackson Laboratory and bred at Princeton University using a heterozygote-heterozygote strategy. For all experiments, 5- to 6-month-old mice were used. Since there is an increased prevalence of ASD among males (Christensen et al., 2012), only male mice were used for these studies ( $n=5-10 /$ group). All mice were group housed in Optimice cages on a reverse $12 \mathrm{~h}$ light/dark cycle.

\section{Immunohistochemistry}

Mice were deeply anesthetized with Euthasol and transcardially perfused with $4 \%$ paraformaldehyde (PFA) in PBS. Following perfusions, brains were postfixed for $48 \mathrm{~h}$ in $4 \%$ PFA followed by cryoprotection with sucrose for 48 h. $40-\mu \mathrm{m}$-thick coronal sections were cut from half brains using a Cryostat (Leica Biosystems). For immature neuron immunolabeling, free-floating sections throughout the hippocampus were rinsed in Tris-buffered saline (TBS) and then incubated with $0.5 \%$ Tween-20, 3\% normal donkey serum, and goat anti-doublecortin (DCX; 1:100; Santa Cruz Biotechnology) in TBS at $4^{\circ} \mathrm{C}$ for 48 h. Sections were then washed and incubated with Alexa Fluor donkey anti-goat 568 (1:250; Invitrogen) for $1 \mathrm{~h}$ at room temperature.

Astrocyte and microglial immunolabeling were conducted separately on free-floating sections that were rinsed in PBS, incubated with 3\% normal donkey serum, PBS with $0.1 \%$ Triton X-100, and rabbit anti-glial fibrillary acidic protein (GFAP; 1:500; Dako), a cytoskeletal astrocyte marker; rabbit anti-S100 (1:10,000, Dako), a Ca ${ }^{2+}$ binding protein that labels astrocyte cell bodies; or rabbit anti-ionized calcium-binding adapter molecule 1 (lba1; 1:500; Wako), a microglial cell body marker; and rat antiCD68 (1:200; Serotec), a microglial lysosomal marker. All tissue was incubated in primary antisera for $24 \mathrm{~h}$ at $4^{\circ} \mathrm{C}$, and then rinsed and incubated with secondary antisera, consisting of either Alexa Fluor donkey anti-rabbit 488 (1:250; Invitrogen) or Alexa Fluor donkey anti-rabbit 568 (1:250; Invitrogen) for astrocyte analyses, or both Alexa Fluor donkey anti-rabbit 488 (1:250; Invitrogen) and Alexa Fluor donkey anti-rat 568 (1:250; Invitrogen) for microglial analyses. Sections were kept in the dark for $1 \mathrm{~h}$, at which point they were rinsed, mounted onto Suprafrost slides, and coverslipped using glycerol in PBS (3:1).

\section{Cell density measurements}

Slides were coded until completion of the data analysis. Since the dorsal and ventral regions of the hippocampus are considered functionally distinct (Fanselow and Dong, 2010), all measures in these regions were analyzed separately (dorsal to bregma, -0.94 to $-3.16 \mathrm{~mm}$; ventral to bregma, -3.16 to $-3.88 \mathrm{~mm}$; Franklin and Paxinos, 2008). For dorsal hippocampus, mPFC, and striatum, four to six sections were analyzed for cell densities. Since the anterior-posterior extent of the ventral hippocampus is relatively small compared with the dorsal hippocampus, fewer sections were analyzed for this subregion (two to three sections). Because the boundaries of the hippocampus were easy to define, quantitative analyses of cell densities (DCX, GFAP, S100, and Iba1) in this brain region were obtained from counts of the overall structure using Stereo Investigator software (Microbrightfield Bioscience). Briefly, the extent of the individual subregions [subgranular zone (SGZ), molecular layer (MOL), and stratum radiatum (RAD)] were outlined, and any positive cells within the delineated region were counted exhaustively. Densities were determined by dividing the total number of positive cells by the volume of the region outlined. Since $\mathrm{GFAP}^{+}$cells in the subgranular zone with radial morphology represent radial-glial-like progenitor cells with stem cell properties (Lugert et al., 2010), GFAP ${ }^{+}$cells exhibiting radial and horizontal morphologies were counted separately. Because the precise boundaries of the MPFC (layers $2 / 3$ ), dorsolateral striatum (DLS), and dorsomedial striatum (DMS) are more difficult to determine, density measurements were made anterior to posterior from the center of each structure following mouse brain atlas coordinates (Franklin and Paxinos, 2008), taking care to avoid the edges, where cells from adjacent structures might be inadvertently included. Cells were counted exhaustively from $20 \mu \mathrm{m}$ image stacks obtained by use of a Zeiss confocal microscope (LSM 700; lasers: argon 458/ 488 , HeNe 568) followed by processing in ImageJ $(\mathrm{NIH})$. Densities were determined by dividing the total number of positive cells by the volume of the region contained in the stack.

\section{Astroglia analyses}

Astroglia morphology was analyzed using $\mathrm{S} 100$ for cell body area and GFAP for cell domain area. Cross-sectional cell body area measurements of $50 \mathrm{~S} \mathrm{CO}^{+}$cells (10-25 cells per section) were randomly selected per animal per brain region (hippocampus, $\mathrm{mPFC}$, and striatum) from a minimum of two sections per brain region per animal. For GFAP domain area analyses, 50 cells per region per animal (10-25 cells per section for each brain region) were randomly selected from a minimum of two sections per brain region per animal and traced by closely following the contours of the distally stained processes using ImageJ (NIH; Oberheim et al., 2009). The $z$-stack images for $\mathrm{S} 100$ and GFAP were obtained using a $20 \times$ objective with $2 \times$ zoom and a $3 \mu \mathrm{m}$ z-step. Because $\mathrm{GFAP}^{+}$cells in the SGZ are either horizontal or radial-glial-like precursor cells, the GFAP domain area was not examined in this subregion.

\section{Microglial analyses}

lba1 ${ }^{+}$microglial cells were analyzed for the number of primary processes, cell body area, and activation status. Cross-sectional cell body area measurements of 10 randomly selected lba $1^{+}$cells (two to five cells per section for each brain region) per animal were obtained from $20 \mu \mathrm{m}$ image $z$-stacks using ImageJ $(\mathrm{NIH})$. The $z$-stack images for Iba $1^{+}$were obtained with a $63 \times$ objective with a $0.7 \times$ zoom and a $0.56 \mu \mathrm{m} z$-step. In order to fully analyze the microglia processes, only Iba1-labeled cells in which the cell body was located toward the middle portion of the $z$-plane were selected for imaging.

$\mathrm{lba} 1^{+}$microglial cells colabeled with lysosomal marker CD68, a marker of microglial activation, were assessed 
using two methods. The first method involved obtaining area measurements of CD68 staining in Iba $1^{+}$cells using a confocal microscope and ImageJ software. The second method was adapted from Schafer et al. (2012) and involved manual counting of CD68-stained aggregates within $\mathrm{Iba}^{+}{ }^{+}$microglial cells. For both methods, $z$-stack images were collected for 10 individual lba $1^{+}$cells (two to five cells per section) from each brain region per animal using a $63 \times$ objective with a $0.7 \times$ zoom and a $0.56 \mu \mathrm{m}$ $z$-step on a Zeiss confocal microscope (LSM 700). Maximum intensity $z$-projections of the image stacks were created using ImageJ $(\mathrm{NIH})$. For the manual counting method, aggregates were counted from the cell body and the processes of each individual microglial cell.

\section{Statistics}

Data collection and analyses were performed by an experimenter who was blind to the animal group. For all experiments, data were analyzed by one-way ANOVA with Bonferroni post hoc comparisons (Table 1), except data sets that violated assumptions of homogeneity of variance or normal distribution (determined by the use of Bartlett's tests). Those datasets were analyzed using Kruskal-Wallis, followed by Dunn's, tests. GraphPad Prism 6.0 (GraphPad Software) was used for all the statistical analyses and graph preparation.

\section{Results}

\section{Immature neurons in the hippocampus}

No differences were detected in the number of $\mathrm{DCX}^{+}$ cells in the dorsal dentate gyrus across mouse models $\left(F_{(2,24)}=0.87, p=0.43\right.$; Fig. $\left.1 A, B\right)$. However, there was a significant difference in the ventral dentate gyrus $\left(F_{(2,15)}=\right.$ $6.18, p=0.01$; Fig. 1C,D). Post hoc analyses showed a statistically significant decrease, such that there was a $>40 \%$ reduction in the mean densities of immature $\mathrm{DCX}^{+}$ neurons in the ventral dentate gyrus in both mouse models of autism compared to wild-type mice (WT vs Cntnap2 $^{-1-}, p=0.02$; WT vs Shank3 ${ }^{+/ \Delta C}, p=0.02$ ).

\section{Astroglia in the hippocampus}

Quantitative analyses of the number of GFAP-stained astrocytes in the dorsal dentate gyrus revealed no significant differences between transgenic and wild-type mice in the SGZ (radial morphology: $F_{(2,23)}=0.09, p=0.91$; horizontal morphology: $F_{(2,23)}=2.03, p=0.15$; Fig. $2 A-C)$, the MOL of the dentate gyrus $(\mathrm{H}=0.98,2 \mathrm{df}, p=$ 0.61 ; Fig. $3 A, B)$, or the RAD of the CA1 region $\left(F_{(2,24)}=\right.$ $0.34, p=0.72$; Fig. $3 A, B)$. Within the ventral SGZ, an overall significant effect in the number of $\mathrm{GFAP}^{+}$cells with radial glial morphology, astroglial cells known to serve as progenitors for new neurons in the adult dentate gyrus, was observed $\left(F_{(2,22)}=6.34, p=0.007\right.$; Fig. $\left.2 D, F\right)$. Post hoc analyses showed a significant decrease in density across both transgenic mouse models compared with wild-type controls (WT vs Cntnap2 ${ }^{-1-}, p=0.007$; WT vs Shank3 ${ }^{+/ \Delta C}, p=0.03$ ). By contrast, no difference was observed in this same region in the number of GFAP ${ }^{+}$ cells with horizontal morphology $\left(F_{(2,22)}=2.15, p=0.14\right.$; Fig. 2E,F). Examination of the proportion of the number of radial glia to the number of $\mathrm{DCX}^{+}$cells revealed no differences in either the dorsal SGZ $\left(F_{(2,23)}=1.37, p=0.27\right)$ or the ventral SGZ $\left(F_{(2,13)}=0.78, p=0.48\right)$. There was an overall statistical significance in the density of $\mathrm{GFAP}^{+}$ cells in the ventral MOL $\left(F_{(2,24)}=3.55, p=0.04\right.$; Fig. $3 D, E)$, but post hoc analysis showed no differences between groups (WT vs Cntnap2 $2^{-1-}, p=0.09$; WT vs Shank3 $\left.{ }^{+/ \Delta C}, p>0.99\right)$. No differences in $\mathrm{GFAP}^{+}$cell density were detected in the ventral $\operatorname{RAD}\left(F_{(2,24)}=0.35, p\right.$ $=0.71$; Fig. $3 D, E)$. A significant decrease in the domain size (the maximum extent of the GFAP-stained processes) of individual $\mathrm{GFAP}^{+}$astrocytes was observed in the dorsal $\operatorname{RAD}\left(F_{(2,24)}=5.13, p=0.01\right)$ in Shank3 ${ }^{+/ \Delta C}$ mice compared with wild-type mice $(p=0.02)$, but this effect was not observed in Cntnap2 $2^{-/-}$mice $(p>0.99)$, which were virtually identical to wild-type mice on this measure. Moreover, the decrease in $\mathrm{GFAP}^{+}$astrocyte domain size was not observed in the dorsal MOL $\left(F_{(2,24)}=1.79, p=\right.$ 0.19 ; Fig. $3 C$ ) or in any of the subregions examined in the ventral hippocampus (MOL: $F_{(2,24)}=1.12, p=0.34$; RAD: $F_{(2,24)}=0.25, p=0.78$; Fig. 3F).

Examination of the astrocyte marker $\mathrm{S} 100$ revealed a slightly different pattern of staining. In the dorsal hippocampus, no significant differences were observed in $\mathrm{S} 100^{+}$cell density or cell body area between transgenic and wild-type mice in the MOL (density: $F_{(2,24)}=2.27, p=$ 0.13 ; cell body area: $\left.F_{(2,24)}=0.39, p=0.68\right)$ or in the RAD (density: $F_{(2,24)}=2.51, p=0.10$; cell body area: $F_{(2,24)}=$ $0.11, p=0.89$; Fig. $4 A-C)$. In the ventral hippocampal subregions, an overall significant difference in $\mathrm{S}_{100}{ }^{+}$cell density was noted (MOL: $F_{(2,24)}=4.56, p=0.02$; RAD: $\left.F_{(2,24)}=4.41, p=0.02\right)$. Post hoc analyses revealed a significant decrease in the density of $\mathrm{S}_{100^{+}}$cells in both the MOL and RAD of Cntnap2 $2^{-1-}$ mice compared with wild-type mice (MOL, $p=0.01$; RAD, $p=0.01$ ). However, no statistical difference was observed on this measure in the Shank $3^{+/ \Delta C}$ mice (MOL, $p=0.31$; RAD, $p=0.51$; Fig. $4 D, E$ ). Furthermore, no statistical differences were observed in cell body area measurements in either the MOL $\left(F_{(2,24)}=0.92, p=0.41\right)$ or $\operatorname{RAD}\left(F_{(2,24)}=0.36, p=0.70\right)$ of the ventral hippocampus (Fig. $4 F$ ).

\section{Microglia in the hippocampus}

Quantitative analyses of the number of $\mathrm{Iba} 1^{+}$microglial cells revealed no overall statistical differences in either the dorsal (MOL: $F_{(2,24)}=0.14, p=0.87$; RAD: $F_{(2,24)}=0.33$, $p=0.72$; Fig. $5 A, B)$ or the ventral (MOL: $F_{(2,24)}=1.60, p$ $=0.22$; RAD: $F_{(2,24)}=0.57, p=0.57$; Fig. $\left.5 D, E\right)$ hippocampus of transgenic mice compared with wild-type mice. Likewise, there was no consistent difference between groups in microglial cell body area (dorsal: MOL: $F_{(2,24)}=0.06, p=0.94$; SGZ: $F_{(2,24)}=0.69, p=0.51$; RAD: $F_{(2,24)}=0.39, p=0.68$; ventral: $\mathrm{MOL}: F_{(2,24)}=0.26$, $p=0.78$; SGZ: $F_{(2,24)}=1.74, p=0.20 ; \mathrm{RAD}: \mathrm{H}=0.40,2$ df, $p=0.82$; Fig. $5 C, F)$ or the number of primary processes (dorsal: MOL: $F_{(2,24)}=1.35, p=0.28$; RAD: $F_{(2,24)}$ $=1.16, p=0.33$; ventral: MOL: $F_{(2,24)}=3.13, p=0.06$; SGZ: $F_{(2,24)}=0.11, p=0.90$; RAD: $F_{(2,24)}=0.60, p=$ $0.56)$. While there was an overall significant difference in the number of primary processes of microglia in the dorsal 
Table 1: Statistical table

\begin{tabular}{|c|c|c|c|c|c|c|c|}
\hline Figure & Description & Data Structure & $\mathrm{HOV}$ & Type of test & $95 \% \mathrm{Cl}$ for $\mathrm{WT}$ & $95 \% \mathrm{Cl}$ for Cntnap2 $2^{-1-}$ & $95 \% \mathrm{Cl}$ for Shank3 ${ }^{+/ \Delta}$ \\
\hline${ }^{1} \mathrm{~B}$ & DCX in the dorsal hippocampus & Normal & Yes & One-way ANOVA & $14,077-17,780$ & $9,654-17,352$ & $11,360-18,927$ \\
\hline${ }^{1} \mathrm{D}$ & DCX in the ventral hippocampus & Normal & Yes & One-way ANOVA & $9,513-17,496$ & $4,572-11,025$ & $6,619-9,370$ \\
\hline \multirow[t]{2}{*}{${ }^{2} \mathrm{C}$} & rGCs and hGCs in the dorsal & Normal & Yes & One-way ANOVA & $8,381-10,624$ (rGCs) & $8,709-10,961$ (rGCs) & $7,668-11,762$ (rGCs) \\
\hline & hippocampus & & & & $15,576-17,671$ (hGCs) & 14,914-16,793 (hGCs) & 15,604-19,204 (hGCs) \\
\hline \multirow[t]{3}{*}{${ }^{2} \mathrm{~F}$} & rGCs and hGCs in the ventral & Normal & Yes & One-way ANOVA & $6,766-10,273$ (rGCs) & $3,469-7,123$ & $4,636-6,844$ \\
\hline & hippocampus & & & & 16,066-19,354 (hGCs) & (rGCs) & (rGCs) \\
\hline & & & & & & 18,018-20,874 (hGCs) & $17,658-21,043$ (hGCs) \\
\hline \multirow[t]{3}{*}{$\mathrm{N} / \mathrm{A}$} & rGCs and DCX cells in the & Normal & Yes & One-way ANOVA & $0.51-0.71$ & $0.59-0.89$ & $0.51-0.82$ \\
\hline & hippocampus & & & & (dorsal) & (dorsal) & (dorsal) \\
\hline & & & & & $0.47-0.82$ (ventral) & $0.57-0.98$ (ventral) & $0.49-0.89$ (ventral) \\
\hline \multirow[t]{2}{*}{${ }^{3} \mathrm{~B}$} & GFAP density in the dorsal & Non-normal (MOL) & No (MOL) & Kruskal-Wallis (MOL & $30,863-35,020$ (MOL) & $31,880-35,640$ (MOL) & 26,868-39,752 (MOL) \\
\hline & hippocampus & Normal (RAD) & Yes (RAD) & One-way ANOVA (RAD) & $27,638-32,713$ (RAD) & $27,138-31,130$ (RAD) & $27,501-32,706$ (RAD) \\
\hline \multirow{2}{*}{${ }^{3} \mathrm{C}$} & GFAP domain area in the dorsal & Normal & Yes & One-way ANOVA & 795-1,063 (MOL) & $756-935$ (MOL) & $731-870$ (MOL) \\
\hline & hippocampus & & & & $912-1,168$ (RAD) & 869-1,202 (RAD) & 630-899 (RAD) \\
\hline \multirow[t]{2}{*}{${ }^{3} \mathrm{E}$} & GFAP density in the ventral & Normal & Yes & One-way ANOVA & $33,738-37,726$ (MOL) & $36,894-40,994$ (MOL) & $30,727-39,249$ (MOL) \\
\hline & hippocampus & & & & $25,884-30,244$ (RAD) & $24,924-29,812$ (RAD) & 23,393-30,019 (RAD) \\
\hline \multirow[t]{2}{*}{${ }^{3} \mathrm{~F}$} & GFAP domain area in the ventral & Normal & Yes & One-way ANOVA & 749-911 (MOL) & $669-860$ (MOL) & $635-860$ (MOL) \\
\hline & hippocampus & & & & $846-1,154$ (RAD) & $825-1,346$ (RAD) & $905-1,185$ (RAD) \\
\hline \multirow{2}{*}{${ }^{4} \mathrm{~B}$} & S100 density in the dorsal & Normal & Yes & One-way ANOVA & $17,245-21,751$ (MOL) & $14,940-17,997$ (MOL) & 12,911-21,489 (MOL) \\
\hline & hippocampus & & & & $15,107-18,016$ (RAD) & $12,518-15,539$ (RAD) & 11,923-18,519 (RAD) \\
\hline${ }^{4} \mathrm{C}$ & S100 morphology in the dorsal & Normal & Yes & One-way ANOVA & $51-64$ (MOL) & 51-65 (MOL) & 44-63 (MOL) \\
\hline & hippocampus & & & & 48-60 (RAD) & $51-60$ (RAD) & 47-63 (RAD) \\
\hline${ }^{4} \mathrm{E}$ & S100 density in the ventral & Normal & Yes & One-way ANOVA & $19,035-25,859$ (MOL) & $14,146-19,274$ (MOL) & 15,336-23,375 (MOL) \\
\hline & hippocampus & & & & $13,518-17,458$ (RAD) & $11,222-13,369$ (RAD) & 11,410-16,797 (RAD) \\
\hline${ }^{4} \mathrm{~F}$ & S100 morphology in the ventral & Normal & Yes & One-way ANOVA & $47-59$ (MOL) & $48-61$ (MOL) & $42-57$ (MOL) \\
\hline & hippocampus & & & & 55-64 (RAD) & 58-64 (RAD) & 53-65 (RAD) \\
\hline${ }^{5} \mathrm{~B}$ & Iba1 density in the dorsal & Normal & Yes & One-way ANOVA & $8,089-10,437$ (MOL) & $8,800-10,325$ (MOL) & $8,742-10,086$ (MOL) \\
\hline & hippocampus & & & & $8,091-9,830$ (RAD) & 8,378-9,594 (RAD) & $8,160-9,113$ (RAD) \\
\hline${ }^{5} \mathrm{C}$ & Iba1 cell body area in the dorsal & Normal & Yes & One-way ANOVA & 44-47 (MOL) & 44-47 (MOL) & 43-48 (MOL) \\
\hline & hippocampus & & & & $41-43$ (SGZ) & 42-44 (SGZ) & $41-45$ (SGZ) \\
\hline & & & & & $41-45$ (RAD) & $42-45$ (RAD) & 42-46 (RAD) \\
\hline $\mathrm{N} / \mathrm{A}$ & Iba1 processes in the dorsal & Normal & Yes & One-way ANOVA & $5.38-6.49$ (MOL) & $5.96-6.82(\mathrm{MOL})$ & $5.56-6.50$ (MOL) \\
\hline & hippocampus & & & & $4.58-5.40$ (SGZ) & $5.11-5.78$ (SGZ) & $5.16-6.36$ (SGZ) \\
\hline & & & & & $5.58-7.46$ (RAD) & $5.05-7.37$ (RAD) & $6.53-7.87$ (RAD) \\
\hline${ }^{5} \mathrm{E}$ & Iba1 density in the ventral & Normal & Yes & One-way ANOVA & $8,799-11,297$ (MOL) & $7,995-9,825$ (MOL) & $8,597-10,955$ (MOL) \\
\hline & hippocampus & & & & $7,208-8,912$ (RAD) & $7,500-9,681$ (RAD) & $7,279-8,814$ (RAD) \\
\hline${ }^{5} \mathrm{~F}$ & Iba1 cell body area in the ventral & Normal (MOL, SGZ) & Yes (MOL, SGZ) & One-way ANOVA (MOL, SGZ) & 43-45 (MOL) & 43-46 (MOL) & 43-46 (MOL) \\
\hline & hippocampus & Non-normal (RAD) & No (RAD) & Kruskal-Wallis (RAD) & 40-46 (SGZ) & 39-45 (SGZ) & 43-47 (SGZ) \\
\hline & & & & & 40-48 (RAD) & 40-46(RAD) & 43-46 (RAD) \\
\hline $\mathrm{N} / \mathrm{A}$ & Iba1 processes in the ventral & Normal & Yes & One-way ANOVA & 5.69-7.19 (MOL) & $6.68-7.78$ (MOL) & $5.32-7.05$ (MOL) \\
\hline & hippocampus & & & & $4.58-5.78$ (SGZ) & $4.83-5.83$ (SGZ) & $4.62-5.44$ (SGZ) \\
\hline & & & & & $5.37-6.95$ (RAD) & $5.34-7.26$ (RAD) & $5.88-7.66$ (RAD) \\
\hline${ }^{6} B$ & CD68 percent area in the dorsal & Normal & Yes & One-way ANOVA & 25-52 (MOL) & 37-64 (MOL) & $36-60$ (MOL) \\
\hline & hippocampus & & & & 30-60 (SGZ) & 23-51 (SGZ) & 29-70 (SGZ) \\
\hline & & & & & 44-71 (RAD) & 46-73 (RAD) & 42-76 (RAD) \\
\hline${ }^{6} \mathrm{D}$ & CD68 percent area in the ventral & Normal (MOL, SGZ) & Yes (MOL, SGZ) & One-way ANOVA (MOL, SGZ) & 34-57 (MOL) & 33-63 (MOL) & 36-60 (MOL) \\
\hline & hippocampus & Non-normal (RAD) & No (RAD) & Kruskal-Wallis (RAD) & 35-65 (SGZ) & 30-54 (SGZ) & 25-66 (SGZ) \\
\hline & & & & & 43-68 (RAD) & 70-75 (RAD) & 48-77 (RAD) \\
\hline $\mathrm{N} / \mathrm{A}$ & CD68 aggregates in the dorsal & Normal & Yes & One-way ANOVA & $1.0-1.7$ (MOL) & $1.4-2.6$ (MOL) & $1.3-2.4$ (MOL) \\
\hline & hippocampus & & & & 2.4-3.3 (SGZ) & 2.6-3.2 (SGZ) & $1.6-2.9$ (SGZ) \\
\hline & & & & & $1.1-1.4$ (RAD) & $1.1-1.8$ (RAD) & $1.1-2.1$ (RAD) \\
\hline $\mathrm{N} / \mathrm{A}$ & CD68 aggregates in the ventral & Normal (MOL, SGZ) & Yes (MOL, SGZ) & One-way ANOVA (MOL, SGZ) & $0.73-1.2$ (MOL) & $0.89-1.7$ (MOL) & $0.85-2.1$ (MOL) \\
\hline & hippocampus & Non-normal (RAD) & No (RAD) & Kruskal-Wallis (RAD) & 2.7-3.9 (SGZ) & 2.8-3.6 (SGZ) & $3.5-4.3$ (SGZ) \\
\hline & & & & & $1.0-1.7$ (RAD) & $1.2-1.8(\mathrm{RAD})$ & $1.0-2.1$ (RAD) \\
\hline${ }^{7} \mathrm{~B}$ & GFAP density in the mPFC & Normal & Yes & One-way ANOVA & $14,284-19,637$ & $15,287-21,324$ & $11,541-21,324$ \\
\hline${ }^{7} \mathrm{C}$ & GFAP domain area in the mPFC & Normal & Yes & One-way ANOVA & $672-894$ & $404-818$ & $558-876$ \\
\hline${ }^{8} \mathrm{~B}$ & S100 density in the mPFC & Normal & Yes & One-way ANOVA & $37,563-42,408$ & $34,360-41,972$ & $33,026-44,822$ \\
\hline${ }^{8} \mathrm{C}$ & S100 cell body area in the mPFC & Normal & Yes & One-way ANOVA & $57-75$ & $54-65$ & $59-76$ \\
\hline${ }^{9} \mathrm{~B}$ & Iba1 density in the mPFC & Normal & Yes & One-way ANOVA & $16,458-20,885$ & $17,605-19,476$ & $14,107-22,088$ \\
\hline${ }^{9} \mathrm{C}$ & Iba1 cell body area in the mPFC & Normal & Yes & One-way ANOVA & $49-59$ & $52-61$ & $53-61$ \\
\hline $\mathrm{N} / \mathrm{A}$ & Iba1 processes in the mPFC & Normal & Yes & One-way ANOVA & $4.27-4.97$ & $4.55-5.11$ & $3.99-5.13$ \\
\hline${ }^{10} \mathrm{~B}$ & CD68 percent area in the mPFC & Normal & Yes & One-way ANOVA & $31-42$ & $28-39$ & $31-53$ \\
\hline N/A & CD68 aggregates in the mPFC & Normal & Yes & One-way ANOVA & $1.9-3.0$ & $2.0-3.2$ & $1.5-2.6$ \\
\hline${ }^{11} \mathrm{~B}$ & GFAP density in the DLS & Normal & Yes & One-way ANOVA & $4,576-9,999$ & $2,227-10,600$ & $3,141-13,608$ \\
\hline${ }^{11} \mathrm{C}$ & GFAP domain area in the DLS & Normal & Yes & One-way ANOVA & $894.1-1,167$ & $893.7-1,281$ & $731.1-1,238$ \\
\hline${ }^{11} \mathrm{E}$ & GFAP density in the DMS & Normal & Yes & One-way ANOVA & $5,431-12,016$ & $4,384-13,134$ & $4,747-15,096$ \\
\hline${ }^{11} \mathrm{~F}$ & GFAP domain area in the DMS & Normal & Yes & One-way ANOVA & $794.6-1,085$ & $791.2-1,137$ & $623.3-1,144$ \\
\hline${ }^{12} \mathrm{~B}$ & S100 density in the DLS & Normal & Yes & One-way ANOVA & $14,376-20,394$ & $15,624-24,349$ & $8,112-18,553$ \\
\hline${ }^{12} \mathrm{C}$ & S100 morphology in the DLS & Normal & Yes & One-way ANOVA & $39.37-46.03$ & $41.13-46.35$ & $39.71-46.62$ \\
\hline${ }^{12} \mathrm{E}$ & S100 density in the DMS & Normal & Yes & One-way ANOVA & $21,978-29,554$ & $20,744-29,426$ & $12,672-23,759$ \\
\hline${ }^{12} \mathrm{~F}$ & S100 morphology in the DMS & Normal & Yes & One-way ANOVA & $42.78-50.88$ & $40.93-49.1$ & $38.35-47.89$ \\
\hline${ }^{13} \mathrm{~B}$ & lba1 density in the DLS & Non-normal & No & Kruskal-Wallis & $8,376-13,633$ & $8,812-11,570$ & $7,593-9,335$ \\
\hline${ }^{13} \mathrm{C}$ & Iba1 cell body area in the DLS & Normal & Yes & One-way ANOVA & $47.11-52.55$ & $46.7-53.66$ & $44.12-49.94$ \\
\hline $\mathrm{N} / \mathrm{A}$ & Iba1 processes in the DLS & Normal & Yes & $\begin{array}{c}\text { One-way ANOVA } \\
\text { (Continued) }\end{array}$ & $5.92-7.52$ & $5.89-7.23$ & $5.80-6.97$ \\
\hline
\end{tabular}


Table 1: Continued

\begin{tabular}{|c|c|c|c|c|c|c|c|}
\hline Figure & Description & Data Structure & $\mathrm{HOV}$ & Type of test & $95 \% \mathrm{Cl}$ for WT & $95 \% \mathrm{Cl}$ for Cntnap2 $2^{-/-}$ & $95 \% \mathrm{Cl}$ for Shank3 ${ }^{+/ \Delta}$ \\
\hline${ }^{13} \mathrm{E}$ & Iba1 density in the DMS & Non-normal & No & Kruskal-Wallis & $7,618-13,277$ & $8,374-10,970$ & $6,749-9,419$ \\
\hline${ }^{13} \mathrm{~F}$ & Iba1 cell body area in the DMS & Normal & Yes & One-way ANOVA & $48.51-55.59$ & $51.05-57.81$ & $45.53-51.25$ \\
\hline $\mathrm{N} / \mathrm{A}$ & Iba1 processes in the DMS & Normal & Yes & One-way ANOVA & $5.25-5.85$ & $5.97-7.45$ & $4.75-6.16$ \\
\hline${ }^{14} \mathrm{~B}$ & CD68 percent area in the DLS & Non-normal & No & Kruskal-Wallis & $62.06-83.87$ & $74.36-80.24$ & $59.26-84.94$ \\
\hline${ }^{14} \mathrm{D}$ & CD68 percent area in the DMS & Non-normal & No & Kruskal-Wallis & $61.11-82.62$ & $75.6-79.02$ & $52.09-84.29$ \\
\hline N/A & CD68 aggregates in the DLS & Non-normal & No & Kruskal-Wallis & $2.43-4.67$ & $3.21-4.11$ & $2.1-3.73$ \\
\hline N/A & CD68 aggregates in the DMS & Normal & Yes & One-way ANOVA & $1.84-3.32$ & $2.14-3.86$ & $1.77-2.95$ \\
\hline
\end{tabular}

hGC, Horizontal glial cell; rGC, radial glial cell.

$\operatorname{SGZ}\left(F_{(2,24)}=4.12, p=0.03\right)$, post hoc analyses showed that this effect was only in Shank $3^{+/ \Delta C}$ mice compared with wild-type mice (WT vs Cntnap2 ${ }^{-1-}, p=0.17$; WT vs Shank3 $\left.{ }^{+/ \Delta C}, p=0.02\right)$.

Analysis of CD68 immunolabeling, an indicator of microglial reactivity, within $\mathrm{lba} 1^{+}$microglia also yielded no statistically significant differences in the percentage of the labeled area among groups for the dorsal hippocampus (MOL: $F_{(2,24)}=1.36, p=0.28$; SGZ: $F_{(2,24)}=0.82, p=$ 0.45 ; RAD: $F_{(2,24)}=0.03, p=0.98$; Fig. $\left.6 A, B\right)$ and the ventral hippocampus (MOL: $F_{(2,24)}=0.07, p=0.93$; SGZ: $F_{(2,24)}=0.39, p=0.68$; RAD: $\mathrm{H}=4.58,2 \mathrm{df}, p=0.10$; Fig. $6 C, D)$. Furthermore, we found no difference in the number of CD68 aggregates in microglia in either the dorsal (MOL: $F_{(2,24)}=2.37, p=0.12$; SGZ: $F_{(2,24)}=2.78, p=0.08$; RAD: $\left.F_{(2,24)}=0.52, p=0.60\right)$ or ventral (MOL: $F_{(2,24)}=$ 1.91, $p=0.17$; SGZ: $F_{(2,24)}=2.62, p=0.09$; RAD: $\mathrm{H}=$ 2.40, $2 \mathrm{df}, p=0.30$ ) hippocampus.

\section{Astroglia in the medial prefrontal cortex}

No significant differences were observed in $\mathrm{GFAP}^{+}$cell density $\left(F_{(2,24)}=0.31, p=0.74\right)$ or domain area $\left(F_{(2,24)}=\right.$ 1.56, $p=0.23)$ in the mPFC when comparing across genotype (Fig. 7). Similar to what was observed for GFAPlabeled tissue in the MPFC, quantitative analyses of S100 ${ }^{+}$density $\left(F_{(2,24)}=0.21, p=0.81\right)$ and cell body area $\left(F_{(2,24)}=1.61, p=0.22\right)$ in the mPFC revealed no significant differences across genotypes (Fig. 8).

\section{A}
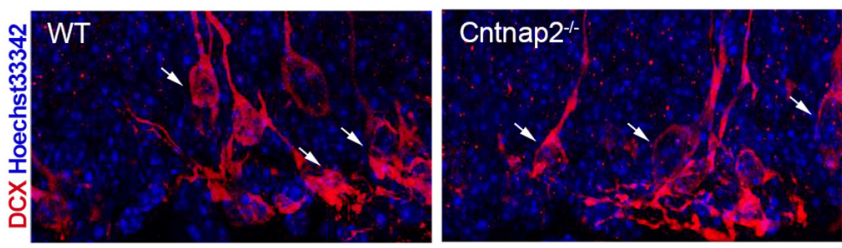

C

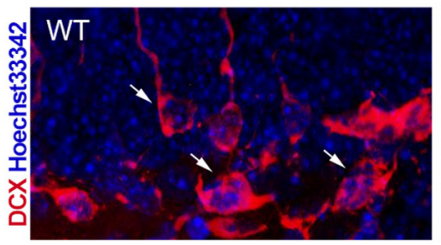

\section{Microglia in the medial prefrontal cortex}

No significant differences in the density of $\mathrm{Iba1}{ }^{+}$microglia $\left(F_{(2,24)}=0.08, p=0.92\right)$ and the cell body area of lba1 $^{+}$microglia $\left(F_{(2,24)}=.64, p=0.54\right)$ were observed across genotypes (Fig. 9). Likewise, no differences in the number of primary processes of $\mathrm{Iba}^{+}$microglia were detected across genotypes $\left(F_{(2,24)}=0.76, p=0.48\right)$.

No differences were observed in microglial activation, as measured by the percentage of the area of CD68 in $\mathrm{Iba}^{+}$cells $\left(F_{(2,24)}=1.93, p=0.17\right.$; Fig. 10$)$ as well as by counting the number of CD68 aggregates in $\mathrm{Iba}^{+}$cells $\left(F_{(2,24)}=1.00, p=0.38\right)$ across genotypes.

\section{Astroglia in the striatum}

No significant differences were observed in the number of $\mathrm{GFAP}^{+}$astrocytes between transgenic and wild-type mice in either the $\operatorname{DLS}\left(F_{(2,24)}=0.39, p=0.68\right.$; Fig. $\left.11 A, B\right)$ or in the DMS $\left(F_{(2,24)}=0.27, p=0.77\right.$; Fig. 11D,E). Furthermore, no differences in the domain sizes of individual $\mathrm{GFAP}^{+}$astrocytes were detected in the DLS $\left(F_{(2,24)}=0.38, p=0.69\right.$; Fig. $\left.11 C\right)$ or in the DMS $\left(F_{(2,24)}=\right.$ $0.24, p=0.79$; Fig. 11F).

Similar to the analysis of $\mathrm{GFAP}^{+}$astrocytes in the striatum, $\mathrm{S} 100^{+}$astrocytes showed no consistent differences between transgenic and wild-type mice in either the DLS $\left(F_{(2,24)}=3.20, p=0.06\right.$; Fig. $\left.12 A, B\right)$ or in the DMS $\left(F_{(2,24)}\right.$ $=4.1, p=0.03$; Fig. $12 D, E)$. Although an overall significant effect was observed for $\mathrm{S} 100^{+}$density in the DMS,

\section{B}
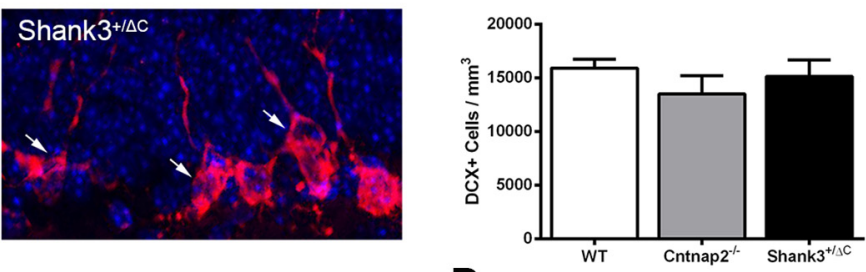

D
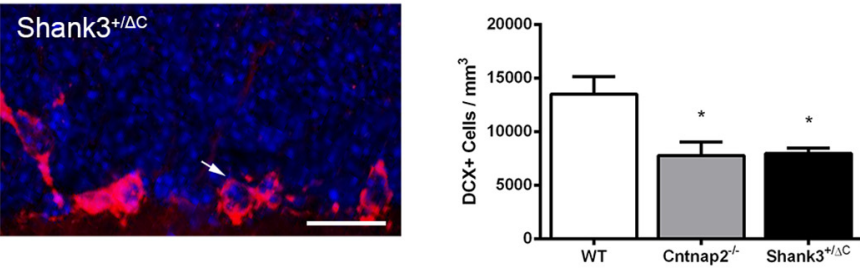

Figure 1. Cntnap $2^{-/-}$and Shank $3^{+/ \Delta C}$ mice have reduced numbers of immature neurons in the ventral dentate gyrus of the hippocampus. $\boldsymbol{A}, \boldsymbol{C}$, Representative images of sections immunolabeled with the immature neuronal marker DCX (red) and counterstained with Hoechst 33342 (blue) from WT, Cntnap2 $2^{-1-}$, and Shank ${ }^{+/ \Delta C}$ mice in the dorsal $(\boldsymbol{A})$ and ventral $(\boldsymbol{C})$ dentate gyrus. Scale bar, $20 \mu \mathrm{m}$, applies to all frames. Arrows point to $\mathrm{DCX}^{+}$cells. $\boldsymbol{B}, \boldsymbol{D}$, Quantification of the number of new neurons in the dorsal $(\boldsymbol{B})$ and ventral $(\boldsymbol{D})$ dentate gyrus. Error bars represent the SEM. $* p<0.05$. 
A

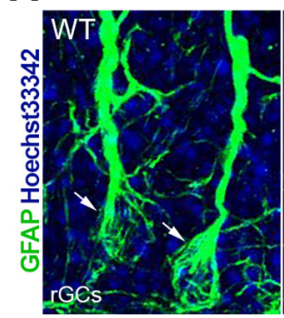

D
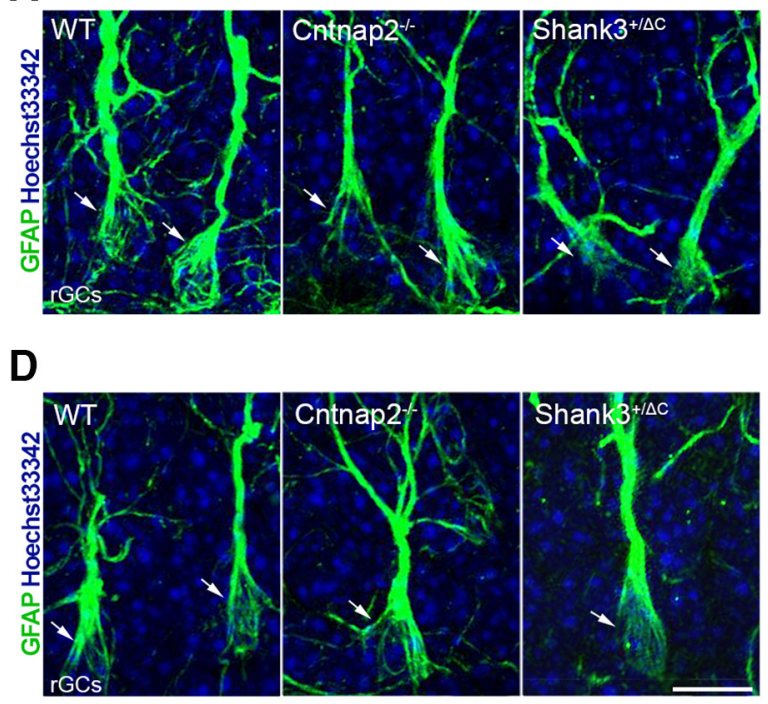

B

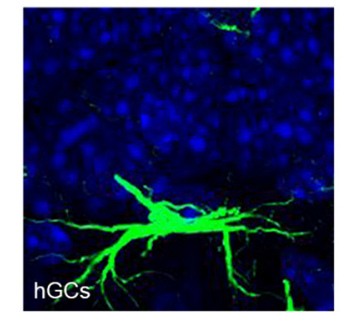

E

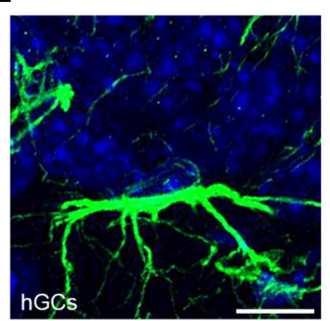

C

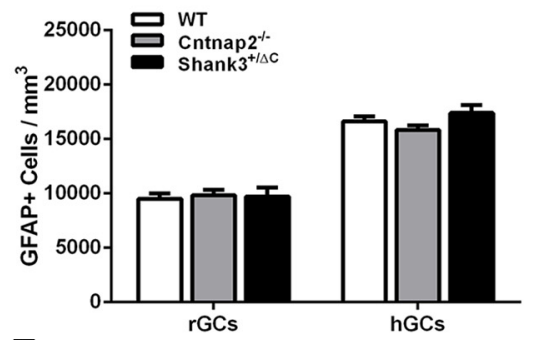

F

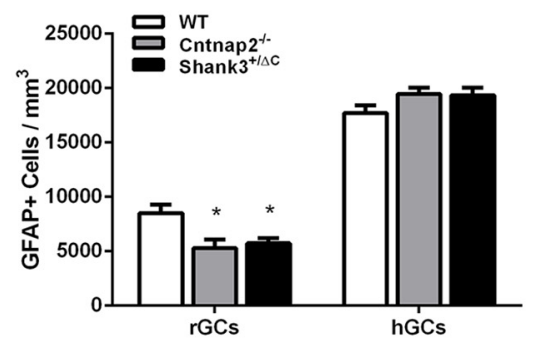

Figure 2. Cntnap $2^{-/-}$and Shank $3^{+/ \Delta C}$ mice have reduced numbers of GFAP-labeled radial glial progenitor cells in the ventral dentate gyrus of the hippocampus $\boldsymbol{A}, \boldsymbol{D}$, Representative images of radial glial cells (rGCs) immunolabeled with astrocyte marker GFAP (green) and counterstained with Hoechst 33342 (blue) from the dorsal $(\boldsymbol{A})$ and ventral $(\boldsymbol{D})$ SGZ. Arrows point to GFAP ${ }^{+}$radial glial cells. Scale bar, $10 \mu \mathrm{m}$, applies to all frames. $\boldsymbol{B}, \boldsymbol{E}$, Representative images of horizontal glial cells (hGCs) from the dorsal $(\boldsymbol{B})$ and ventral $(\boldsymbol{E})$ SGZ. Scale bar, $10 \mu \mathrm{m}$, applies to all frames. $\boldsymbol{C}, \boldsymbol{F}$, Quantification of the density of GFAP-labeled cells with radial glial morphology and horizontal morphology in the dorsal $(\boldsymbol{C})$ and ventral $(\boldsymbol{F})$ SGZ. Error bars represent the SEM. $* p<0.05$.

post hoc comparisons revealed a significant decrease only in Shank3 ${ }^{+/ \Delta C}$ mice compared with wild-type mice (WT vs Shank3 ${ }^{+/ \Delta C}, p=0.03$ ). This effect was not seen in Cntnap2 $^{-1-}$ mice (WT vs Cntnap2 $2^{-1-}, p>0.99$ ). Furthermore, no differences in $\mathrm{S} 100^{+}$cell body area were detected in the DLS $\left(F_{(2,24)}=0.16, p=0.85\right.$; Fig. 12C) or in the DMS $\left(F_{(2,24)}=0.93, p=0.41\right.$; Fig. $\left.12 F\right)$.

\section{Microglia in the striatum}

There were no differences in the density of $\mathrm{Iba}^{+} \mathrm{mi}^{-}$ croglia among the two transgenic models and wild-type mice in either the DLS $(\mathrm{H}=4.66,2 \mathrm{df}, p=0.098$; Fig. $13 A, B)$ or the DMS $(H=3.16,2 d f, p=0.21$; Fig. $13 D, E)$. Likewise, there was no overall statistical difference in microglial cell body area among transgenic models and wild-type mice in the DLS $\left(F_{(2,24)}=1.38, p=0.27\right.$; Fig. $13 C)$. Although an overall significant effect was observed for $\mathrm{Iba} 1^{+}$cell body area in the DMS $\left(F_{(2,24)}=3.76, p=\right.$ 0.04; Fig. 13F), post hoc analysis revealed no significant differences between transgenic and wild-type mice (WT vs Shank3 $^{+/ \Delta C}, p=0.22$; WT vs Cntnap2 ${ }^{-/-}, p=0.49$ ). No significant difference in the number of primary pro-
A

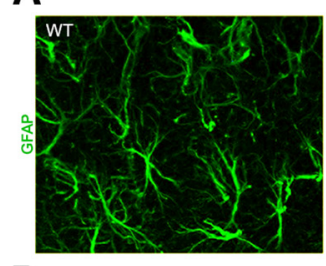

D

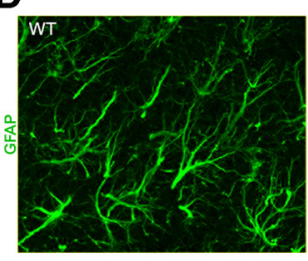

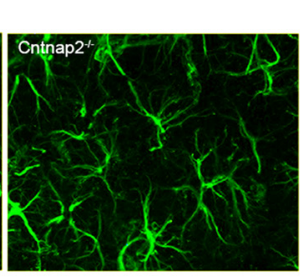

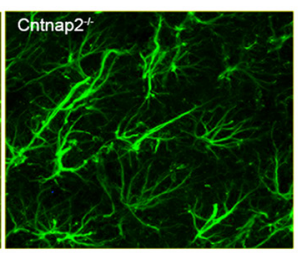

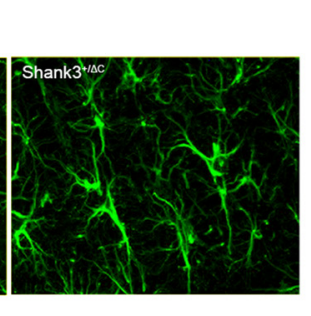

B
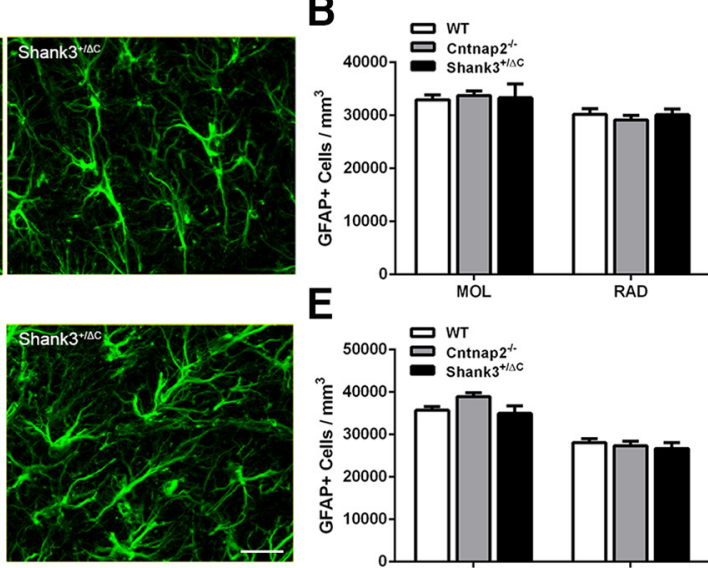

E

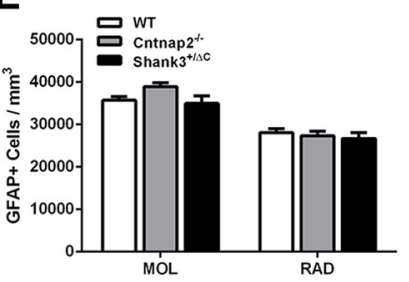

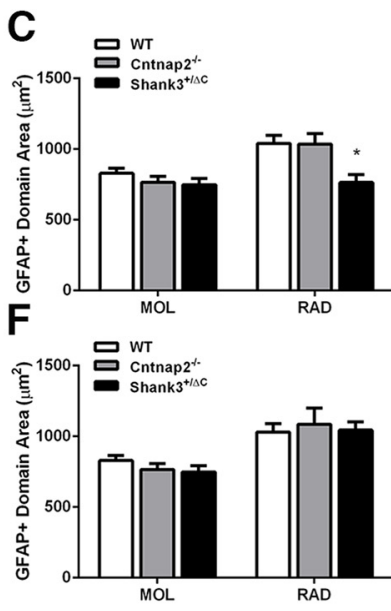

Figure 3. No consistent differences were observed in GFAP-labeled astrocyte density or domain size across mouse autism models in the hippocampus. $\boldsymbol{A}, \boldsymbol{D}$, Representative images of sections immunolabeled with astrocyte marker GFAP (green) from WT, Cntnap2 ${ }^{-1-}$, and Shank3 ${ }^{+/ \Delta C}$ mice in the dorsal $(\boldsymbol{A})$ and ventral $(\boldsymbol{D}) \mathrm{MOL}$ of the dentate gyrus. Scale bar, $20 \mu \mathrm{m}$, applies to all frames. $\boldsymbol{B}, \boldsymbol{E}$, Quantification of the density of GFAP-labeled astrocytes in the dorsal $(\boldsymbol{B})$ and ventral $(\boldsymbol{E})$ hippocampus. $\boldsymbol{C}, \boldsymbol{F}, \mathbf{Q u a n t i f i c a t i o n}$ of GFAP cell domain area in the dorsal $(\boldsymbol{C})$ and ventral $(\boldsymbol{F})$ hippocampus. Error bars represent the SEM. $* p<0.05$. 
A

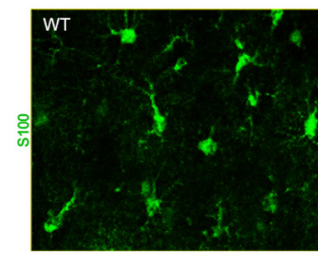

D

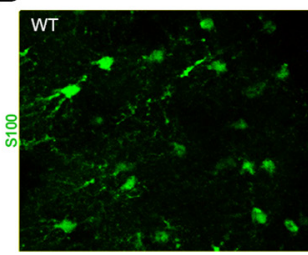

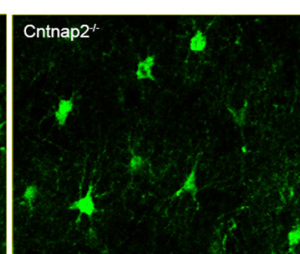

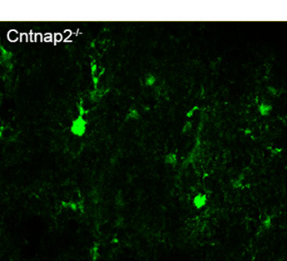

B
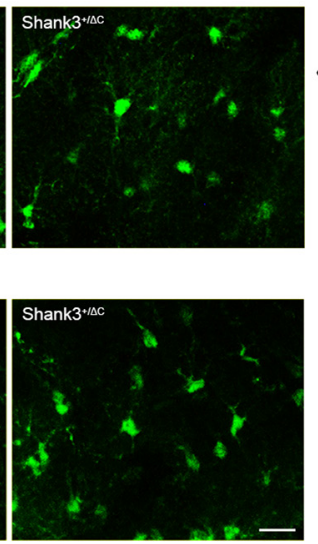

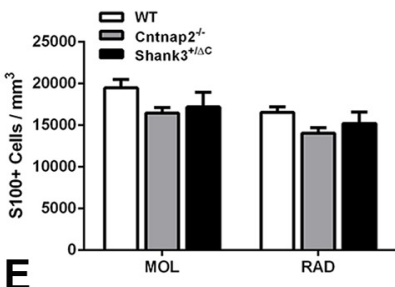

E

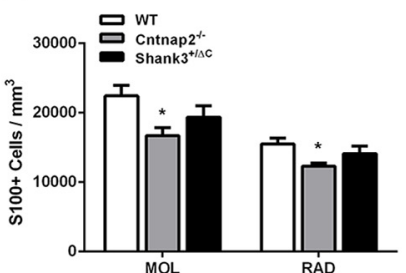

C

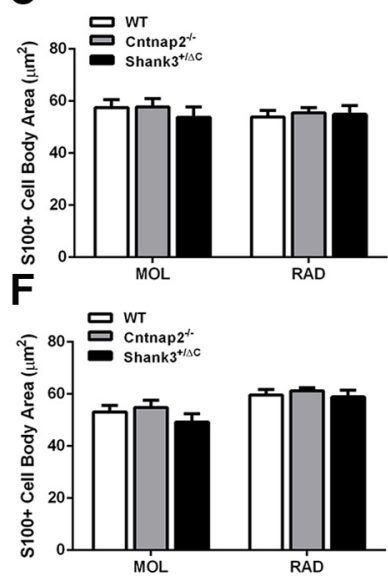

Figure 4. No consistent differences were observed in S100-labeled astrocyte density or cell body size across mouse autism models in the hippocampus. $\boldsymbol{A}, \boldsymbol{D}$, Representative images of sections immunolabeled with astrocyte marker S100 (green) from WT, Cntnap2 ${ }^{-1-}$, and Shank3 ${ }^{+/ \Delta C}$ mice in the dorsal $(\boldsymbol{A})$ and ventral $(\boldsymbol{D}) \mathrm{MOL}$ of the dentate gyrus. Scale bar, $20 \mu \mathrm{m}$, applies to all frames. $\boldsymbol{B}, \boldsymbol{E}$, Quantification of the density of S100-labeled astrocytes in the dorsal $(\boldsymbol{B})$ and ventral $(\boldsymbol{E})$ hippocampus. $\boldsymbol{C}, \boldsymbol{F}, \mathrm{Quantification}$ of S100 cell body area in the dorsal $(\boldsymbol{C})$ and ventral $(\boldsymbol{F})$ hippocampus. Error bars represent the SEM. $* p<0.05$.

cesses of $\mathrm{Iba1}^{+}$microglia was detected in the DLS across genotype $\left(F_{(2,24)}=0.26, p=0.77\right)$. Although an overall significant effect for the number of primary processes of $\mathrm{Iba1}^{+}$microglia was observed in the DMS $\left(F_{(2,24)}=7.42\right.$, $p=0.0031$, post hoc analysis revealed a significant decrease only in Cntnap $2^{-1-}$ mice compared with wildtype mice (WT vs Cntnap2 $2^{-/-}, p=0.0058$ ). This effect was not seen in Shank3 ${ }^{+/ \Delta C}$ mice (WT vs Shank3 ${ }^{+/ \Delta C}, p>$ 0.99).

Iba1 ${ }^{+}$microglial cells were also analyzed for microglial activation through colabeling with CD68. Quantitative analysis of $\mathrm{CD}^{+} 8^{+}$percent area revealed no significant effect in the DLS $(\mathrm{H}=0.32,2 \mathrm{df}, p=0.85$; Fig. 14A,B). Similarly, no significant difference in microglial activation was seen in the DMS $(\mathrm{H}=0.75,2 \mathrm{df}, p=0.69$; Fig. $14 C, D)$. Additionally, the number of CD68 aggregates in
$\mathrm{Iba1}^{+}$cells revealed no significant differences across genotype in either the DLS $(\mathrm{H}=1.88,2 \mathrm{df}, p=0.39)$ or the $\operatorname{DMS}\left(F_{(2,24)}=0.89, p=0.42\right)$.

\section{Differences in astroglia across brain regions}

In our study, no consistent glial differences were found between wild-type and autism mouse models within the hippocampus, mPFC, or striatum other than in specialized astroglia in the SGZ known to serve as progenitor cells for immature neurons. Microscopic analyses of GFAP $^{+}$cells with astrocyte morphology revealed different profiles among the hippocampus, mPFC, and striatum (Figs. 2, 3, $7,11)$. The density of GFAP-labeled cells (per cubic millimeter) in the dentate gyrus molecular layer and CA1 stratum radiatum of the hippocampus far exceeded that of both the mPFC and striatum. Furthermore, GFAP-
A
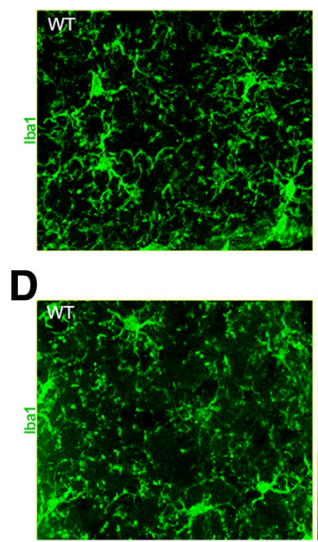
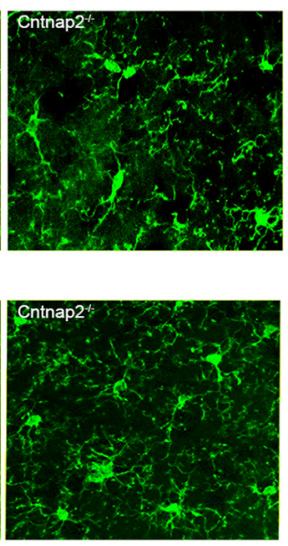
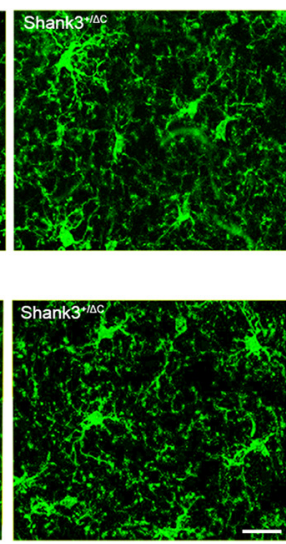

B
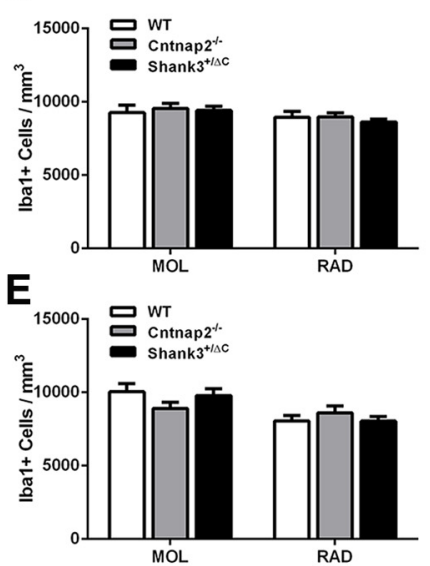

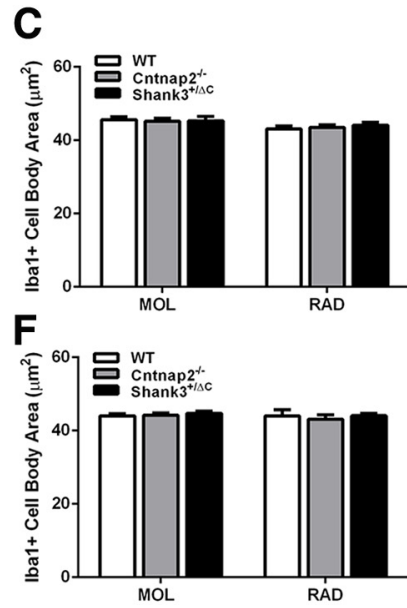

Figure 5. No differences were detected in lba1-labeled microglia density and cell body size across mouse autism models in the hippocampus. $\boldsymbol{A}, \boldsymbol{D}$, Representative images of sections immunolabeled with microglia marker lba1 (green) from WT, Cntnap2 ${ }^{-\prime-}$, and Shank3 ${ }^{+/ \Delta C}$ mice in the dorsal $(\boldsymbol{A})$ and ventral $(\boldsymbol{D}) \mathrm{MOL}$ of the dentate gyrus. Scale bar, $20 \mu \mathrm{m}$, applies to all frames. $\boldsymbol{B}$, $\boldsymbol{E}$, Quantification of the density of Iba1-labeled microglia in the dorsal $(\boldsymbol{B})$ and ventral $(\boldsymbol{E})$ hippocampus. $\boldsymbol{C}, \boldsymbol{F}$, Quantification of Iba1 cell body area in the dorsal $(\boldsymbol{C})$ and ventral $(\boldsymbol{F})$ hippocampus. Error bars represent the SEM. 
A

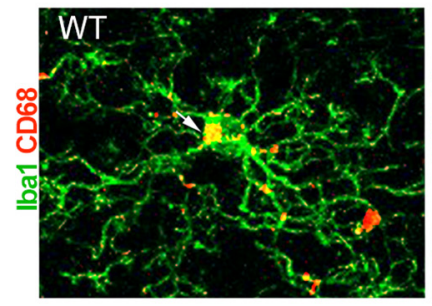

C

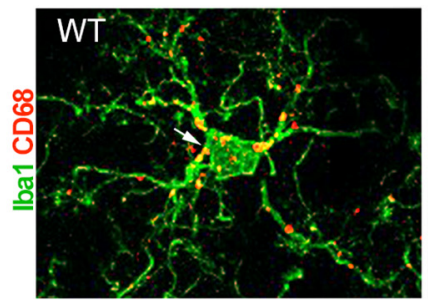

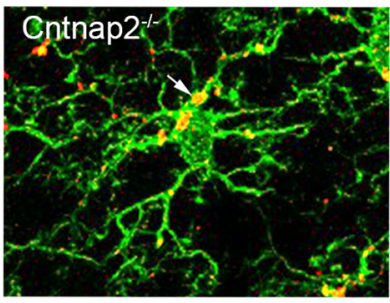
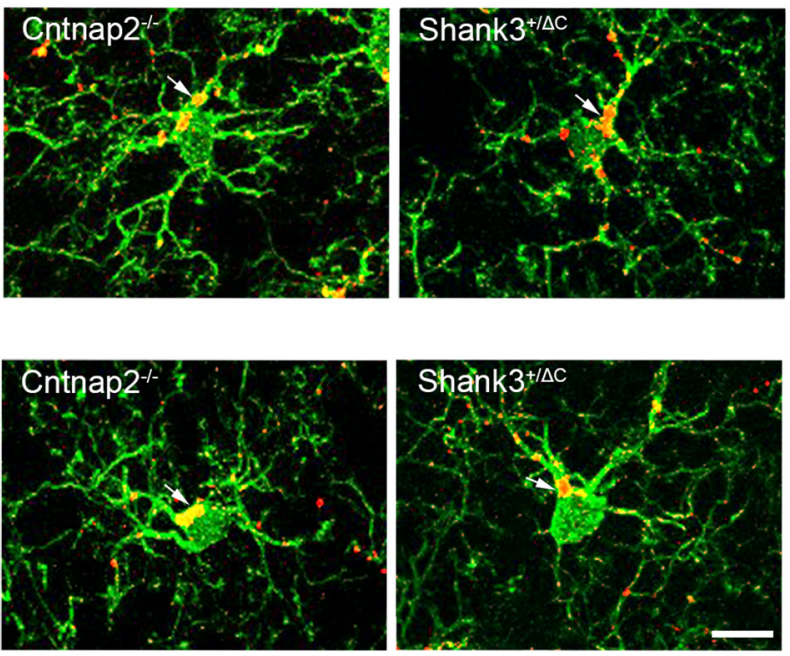

\section{B}

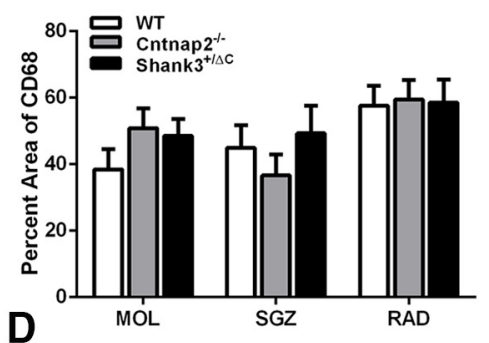

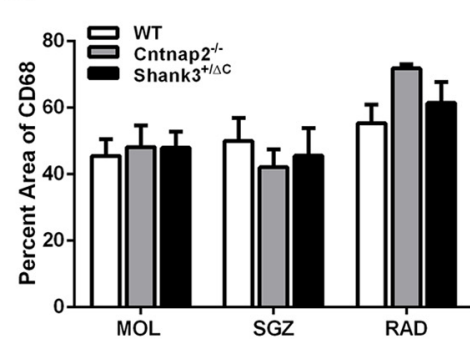

Figure 6. No differences were detected in the percentage area of CD68 in $\mathrm{lba1}{ }^{+}$cells across mouse autism models in the hippocampus. $\boldsymbol{A}, \boldsymbol{C}$, Representative images of sections double labeled with microglia marker lba1 (green) and microglial lysosomal marker CD68 (red) from WT, Cntnap2 ${ }^{-1-}$, and Shank3 ${ }^{+/ \Delta C}$ mice in the dorsal $(\boldsymbol{A})$ and ventral $(\boldsymbol{C})$ MOL of the dentate gyrus. Arrows point to CD68 aggregate labeling. Scale bar, $10 \mu \mathrm{m}$, applies to all frames. $\boldsymbol{B}, \boldsymbol{D}$, Quantification of the percentage area of CD68 in Iba1-labeled microglia cells in the dorsal $(\boldsymbol{B})$ and ventral $(\boldsymbol{D})$ hippocampus. Error bars represent the SEM.

labeled astrocytes in the mPFC were on average smaller in domain area compared with the hippocampus and striatum. The overall shape of the GFAP-labeled cells differed; astrocytes in the MPFC appeared to be more spherical in shape with more elaborate branched processes than those in the hippocampus (compare Figs. 3,7 ). Similar differences in appearance were seen between the striatum and hippocampus, where astrocytes in the striatum appeared to have more branched pro- cesses in a spherical pattern, but were similar in domain area (compare Figs. 3, 11). Analyses from S100 cells also revealed regional differences in cell density and size. The density of $\mathrm{S} 100^{+}$cells (per cubic millimeter) in the mPFC was approximately twice that of the DLS and dentate gyrus molecular layer and CA1 stratum radiatum of the hippocampus. Additionally, the average DLS cell body area of $\mathrm{S}^{100^{+}}$cells was smaller than all other regions (compare Figs. 4, 8, 12).
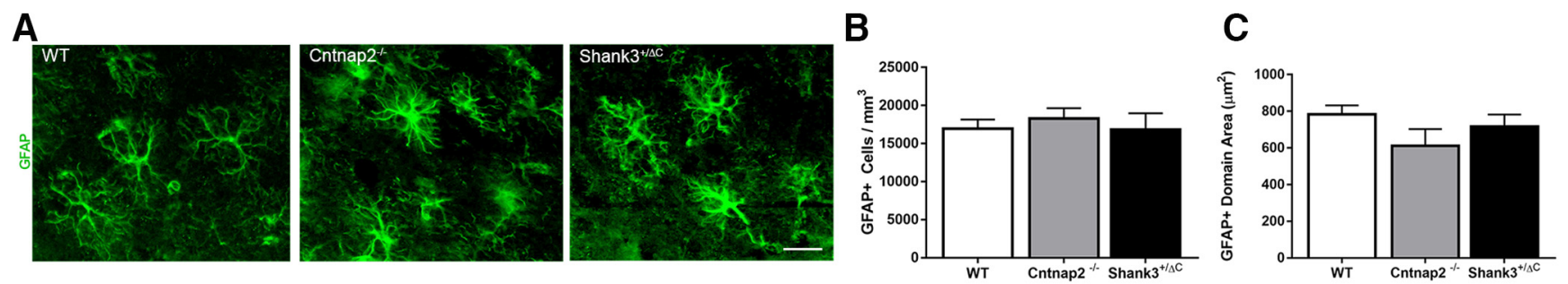

Figure 7. No differences in GFAP-labeled astrocyte density or domain size were detected in the mPFC. $\boldsymbol{A}$, Representative images of sections immunolabeled with GFAP (green) in the mPFC. Scale bar, $20 \mu \mathrm{m}$, applies to all frames. B, Quantitative analysis of GFAP density in the mPFC. $\boldsymbol{C}$, Quantitative analysis of GFAP domain area in the mPFC. Error bars represent the SEM.

A

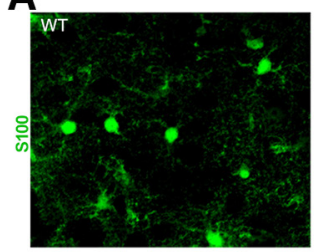

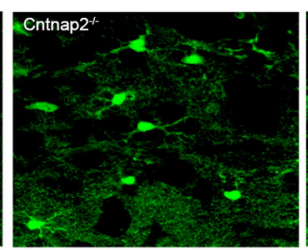

B

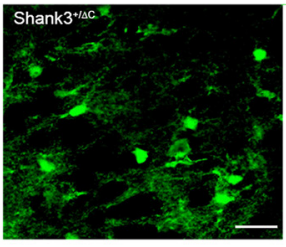

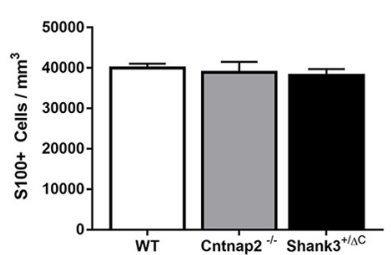

C

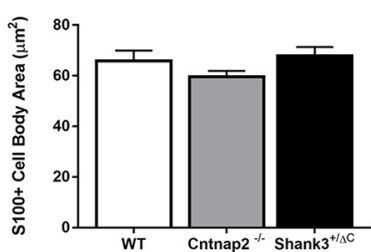

Figure 8. No differences in astrocyte number or cell body size were detected in the mPFC using the astrocytic marker S100. $\boldsymbol{A}$, Representative images of sections immunolabeled with $\mathbf{S} 100$ (green) in the mPFC. Scale bar, $20 \mu \mathrm{m}$, applies to all frames. $\boldsymbol{B}$, Quantitative analysis of S100 density in the mPFC. C, Quantitative analysis of S100 cell body area in the mPFC. Error bars represent the SEM. 
A

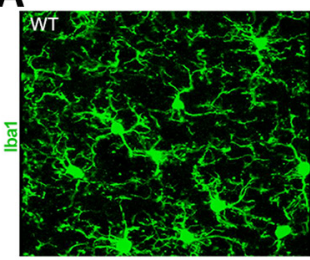

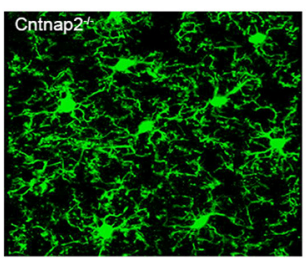

B

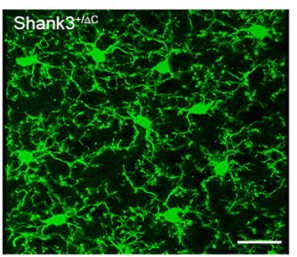

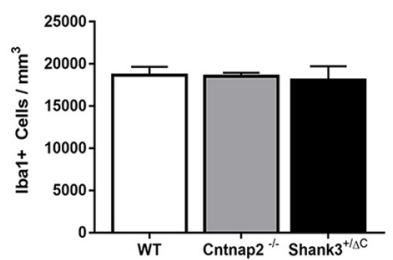

C

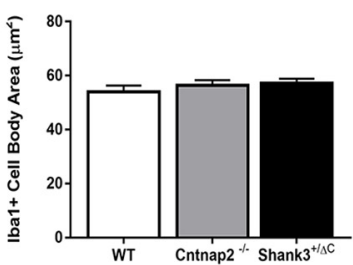

Figure 9. No differences in lba1-labeled microglia density or cell body size were detected in the mPFC across groups. $\boldsymbol{A}$, Representative images of sections immunolabeled with lba1 (green) in the mPFC. Scale bar, $20 \mu \mathrm{m}$, applies to all frames. $\boldsymbol{B}$, Quantitative analysis of Iba1 density in the mPFC. C, Quantitative analysis of Iba1 cell body area in the mPFC. Error bars represent the SEM.

\section{Discussion}

We searched for similar differences in markers of neuronal and glial plasticity in three brain regions in two genetic models of autism compared with wild-type controls. Of the measures we made, the only ones that exhibited similar differences across both ASD mouse models were those related to adult neurogenesis in the hippocampus, namely, the number of doublecortin- labeled cells and the number of radial glial-like progenitor cells. We observed no consistent changes in any other markers of glial plasticity, including the number or size of astrocytes in the hippocampus, MPFC, or striatum, and no differences in the number, size, or activation of microglia in the aforementioned brain regions across both genotypes. Despite not finding consistent differences in markers of astrocytes or microglia across genotypes, dif-
A

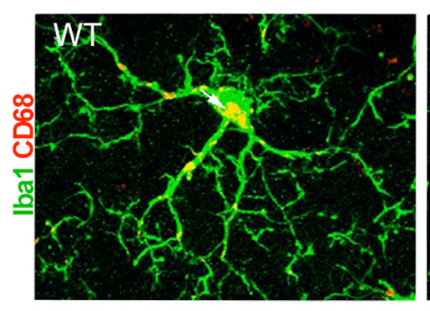

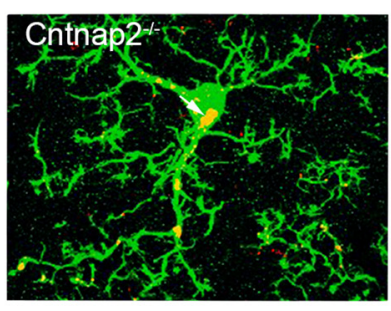

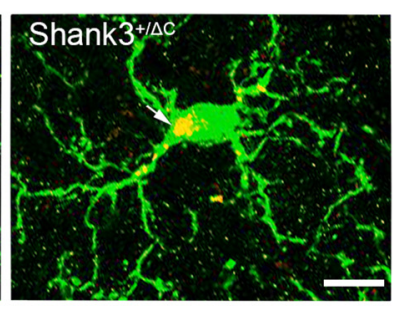

B

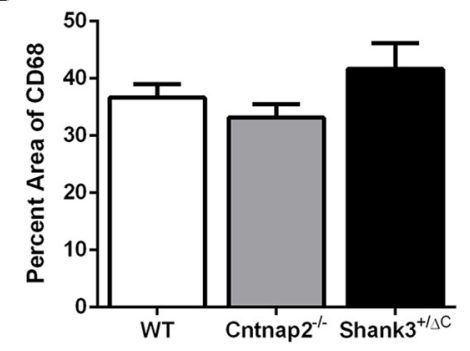

Figure 10. No differences were detected in the percentage area of CD68 in lba1 ${ }^{+}$cells across mouse autism models in the mPFC. $\boldsymbol{A}$, Representative images of sections double labeled with microglia marker lba1 (green) and microglial lysosomal marker CD68 (red) from WT, Cntnap2 $2^{-1-}$, and Shank3 ${ }^{+/ \Delta C}$ mice in the mPFC. Scale bar, $10 \mu \mathrm{m}$, applies to all frames. Arrows point to CD68 aggregate labeling. B, Quantification of the percentage area of CD68 in Iba1-labeled microglia cells in the mPFC. Error bars represent the SEM.

A

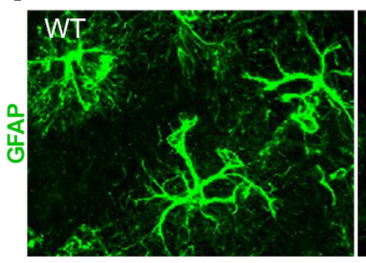

D

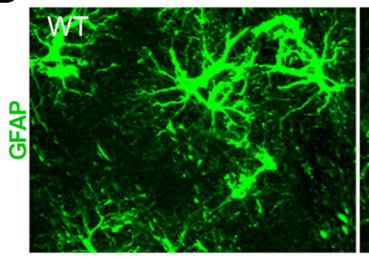

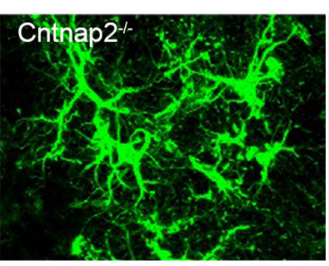

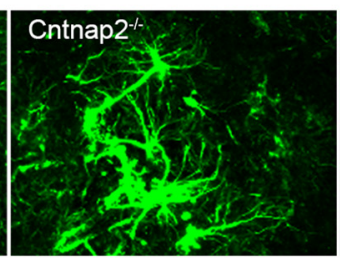

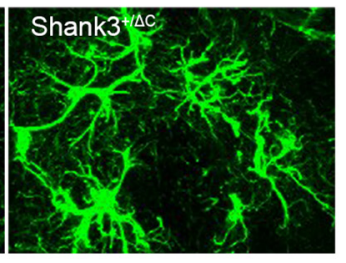

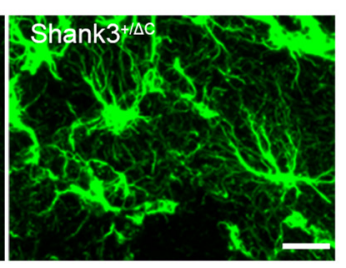

B

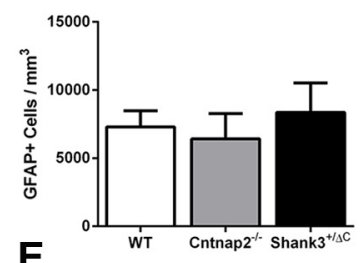

E

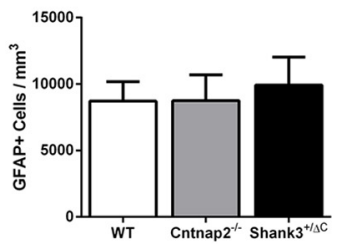

C
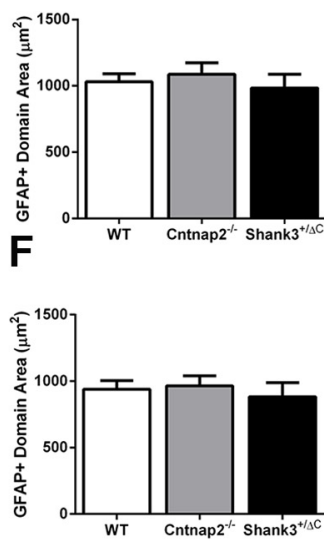

Figure 11. No differences were observed in GFAP-labeled astrocyte number and domain size across mouse autism models in the dorsal striatum. $\boldsymbol{A}, \boldsymbol{D}$, Representative images of sections immunolabeled with GFAP (green) from WT, Cntnap2 ${ }^{-/-}$, and Shank3 ${ }^{+/ \Delta C}$ mice in the DLS $(\boldsymbol{A})$ and DMS $(\boldsymbol{D})$. Scale bar, $20 \mu \mathrm{m}$, applies to all frames. $\boldsymbol{B}, \boldsymbol{E}$, Quantification of the density of GFAP-labeled astrocytes in the DLS $(\boldsymbol{B})$ and DMS $(\boldsymbol{E}) . \boldsymbol{C}, \boldsymbol{F}$, Quantification of cell domain area of GFAP-labeled astrocytes in the DLS (C) and DMS (F). Error bars represent the SEM. 
A
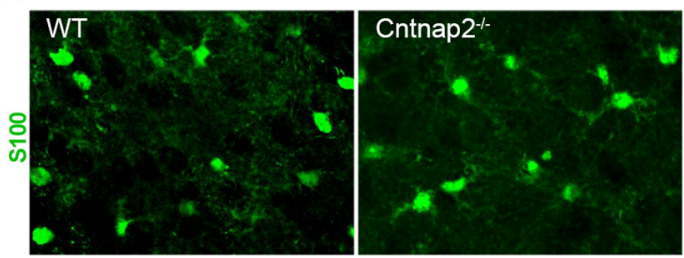

D
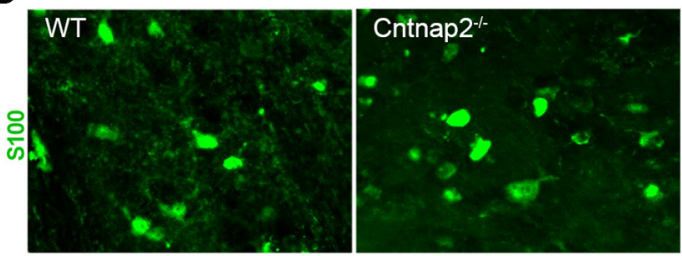

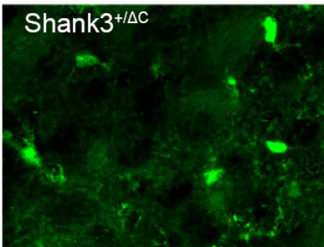

B

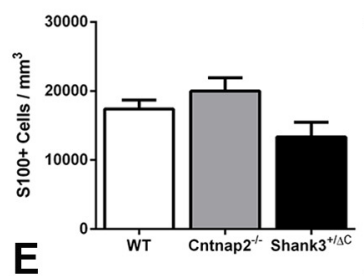

E

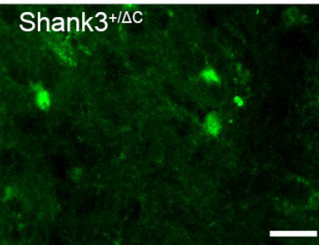

C
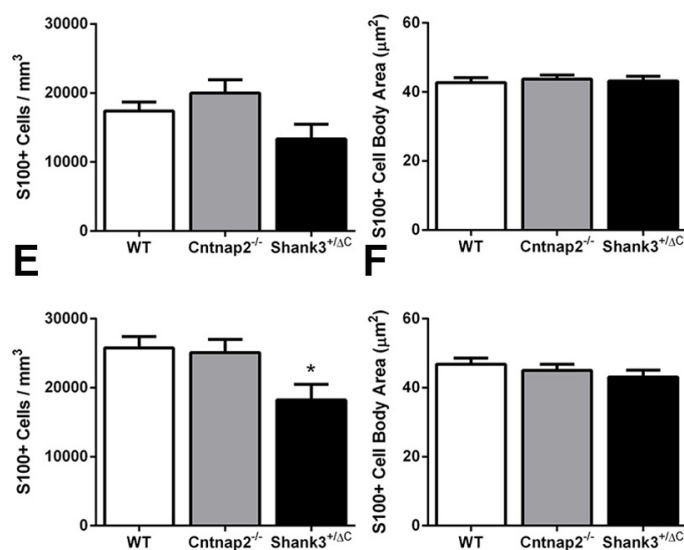

Figure 12. No consistent differences were observed in S100-labeled astrocyte number and cell body size across mouse autism models in the dorsal striatum. $\boldsymbol{A}, \boldsymbol{D}$, Representative images of sections immunolabeled with S100 (green) from WT, Cntnap2 ${ }^{-1-}$, and Shank3 $3^{+/ \Delta C}$ mice in the DLS $(\boldsymbol{A})$ and DMS $(\boldsymbol{D})$. Scale bar, $20 \mu \mathrm{m}$, applies to all frames. $\boldsymbol{B}, \boldsymbol{E}$, Quantification of the density of S100-labeled astrocytes in the DLS $(\boldsymbol{B})$ and DMS $(\boldsymbol{E})$. $\boldsymbol{C}, \boldsymbol{F}$, Quantification of cell body area of S100-labeled astrocytes in the DLS (C) and DMS $(\boldsymbol{F})$. Error bars represent the SEM. $* p<0.05$.

ferences between genotypes unique to particular cell types were detected in both the hippocampus and striatum. In the hippocampus, $\mathrm{GFAP}^{+}$cell domain areas were smaller in the dorsal stratum radiatum of Shank ${ }^{+/ \Delta C}$ animals relative to wild-type controls. Similarly, fewer $\mathrm{S}_{100^{+}}$cells were found in Cntnap2 $2^{-/-}$animals in the dorsal molecular layer and stratum radiatum of the hippocampus. In the dorsomedial striatum, fewer $\mathrm{S}_{100^{+}}$ cells were detected in Shank $3^{+/ \Delta C}$ mice. Collectively, these findings suggest that shared differences in adult neurogenesis exist, but that potential differences in glial plasticity associated with ASD may be more subtle, and not necessarily general findings, in the adult brain.

We found a robust decrease in the number of new neurons, as well as in the number of radial glial-like progenitor cells, in the ventral, but not dorsal, dentate gyrus in both Cntnap $2^{-/-}$and Shank $3^{+/ \Delta C}$ transgenic mice. The specificity of this finding to the ventral part of the hippocampus may be functionally relevant as, in the rodent, the ventral hippocampus has been linked to anxiety and stress regulation, whereas the dorsal hippocampus has been linked to spatial navigation learning and memory (Fanselow and Dong, 2010). Since ASD has high comorbidity with anxiety disorders (Simonoff et al., 2008; van Steensel et al., 2011), reduced numbers of new neurons may contribute to increased anxiety. Recent evidence suggests that, in addition to anxiety regulation, new neurons in the ventral dentate gyrus may mediate some social behaviors (Opendak et al., 2016). Our adult neurogenesis findings are in line with behavioral data showing that Cntnap2 $2^{-1-}$ and Shank3 ${ }^{+/ \Delta C}$ transgenic mice display more anxiety-like behaviors and deficits in social behav-
A

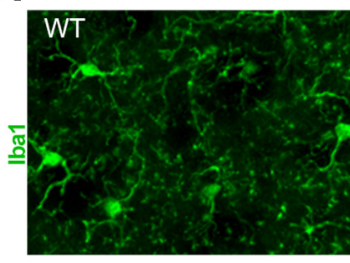

D

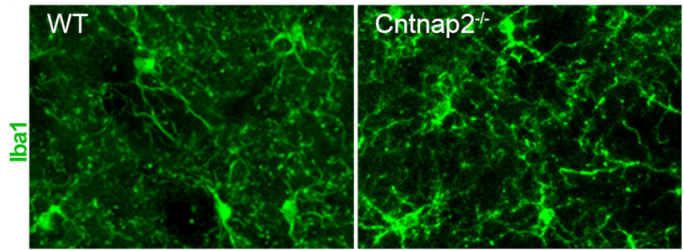

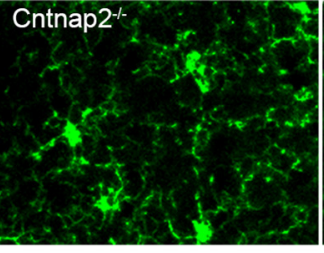
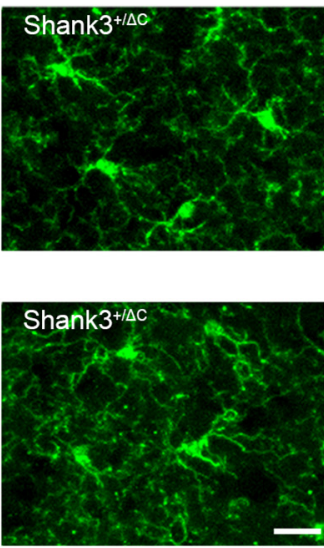

B
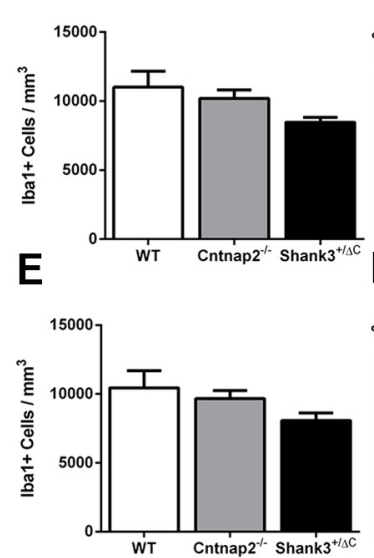

C
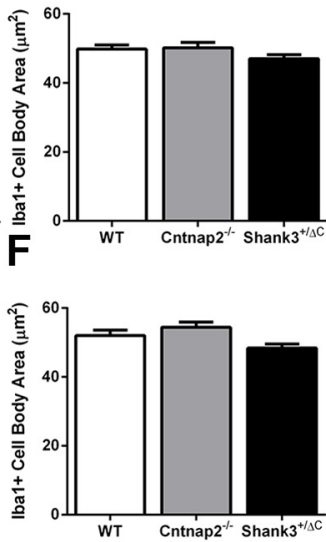

Figure 13. No consistent differences were observed in Iba1-labeled microglia number and cell body size across mouse models in the dorsal striatum. $\boldsymbol{A}, \boldsymbol{D}$, Representative images of sections immunolabeled with Iba1 (green) from WT, Cntnap2 $2^{-/-}$, and Shank3 ${ }^{+/ \Delta C}$ mice in the DLS $(\boldsymbol{A})$ and DMS $(\boldsymbol{D})$. Scale bar, $20 \mu \mathrm{m}$, applies to all frames. $\boldsymbol{B}, \boldsymbol{E}$, Quantification of the density of lba1-labeled microglia in the DLS $(\boldsymbol{B})$ and DMS $(\boldsymbol{E})$. $\boldsymbol{C}, \boldsymbol{F}$, Quantification of the cell body area of lba1-labeled microglia in the DLS $(\boldsymbol{C})$ and DMS $(\boldsymbol{F})$. Error bars represent the SEM. 
A
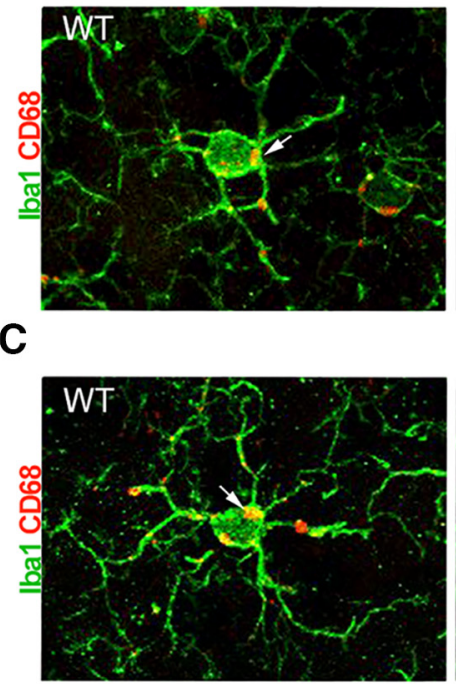
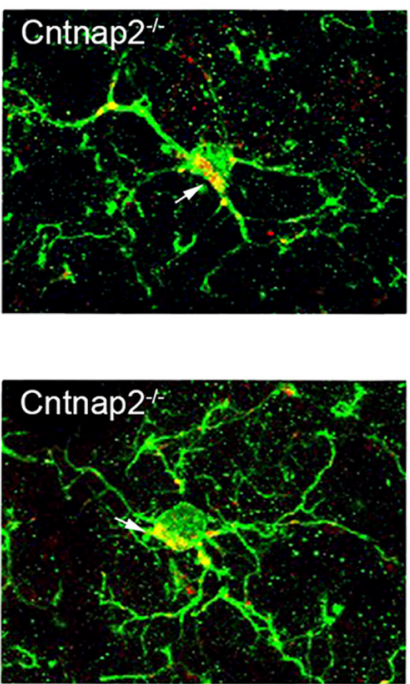
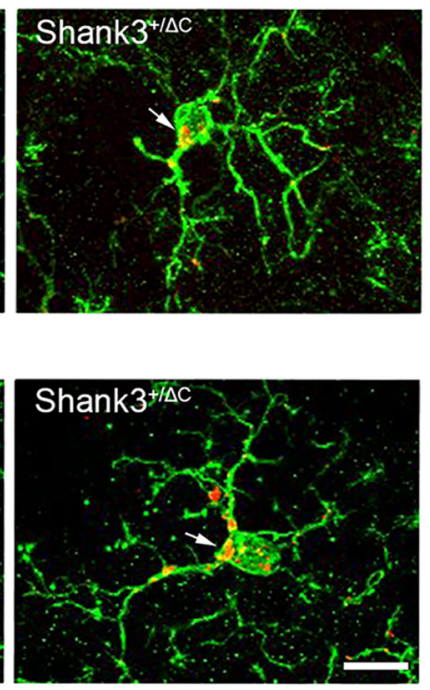

\section{B}
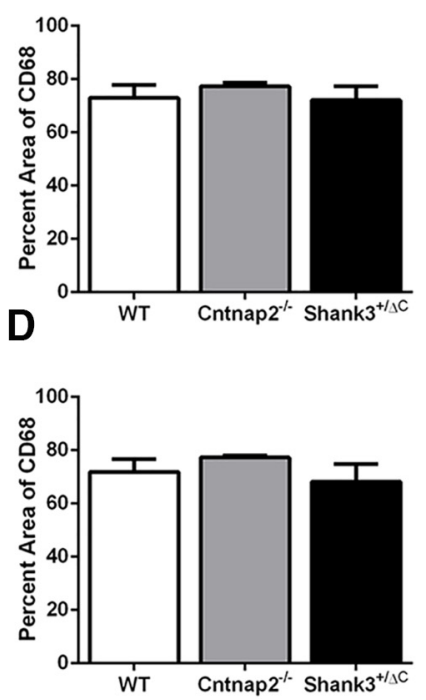

Figure 14. No differences were detected in the percentage area of CD68 in lba1 ${ }^{+}$cells across mouse autism models in the dorsal striatum. $\boldsymbol{A}, \boldsymbol{C}$, Representative images of sections immunolabeled with lba1 (green) and microglial lysosomal marker CD68 (red) from WT, Cntnap2 $2^{-1-}$, and Shank $3^{+/ \Delta C}$ mice in the DLS $(\boldsymbol{A})$ and DMS $(\boldsymbol{C})$. Arrows point to CD68 aggregate labeling. Scale bar, $10 \mu \mathrm{m}$, applies to all frames. $\boldsymbol{B}, \boldsymbol{D}$, Quantification of the percentage area of CD68 in lba1-labeled microglia cells in DLS $(\boldsymbol{B})$ and DMS $(\boldsymbol{D})$. Error bars represent the SEM.

iors compared to wild-type mice (Peñagarikano et al., 2011; Duffney et al., 2015). Additionally, our data are also consistent with another study that showed that the BTBR mouse strain, which exhibits many behavioral deficits associated with ASD, has reduced the numbers of adultborn neurons in the hippocampus (Stephenson et al., 2011). However, this study did not differentiate between the dorsal and ventral portions of the dentate gyrus. To determine whether reduced numbers of immature neurons are a general phenomenon of ASD, future work should explore markers of adult neurogenesis in other mouse models, as well as in postmortem human ASD tissue.

Despite clear differences in the numbers of new neurons and astroglial progenitor cells in the ventral hippocampus, we detected no consistent differences across genotypes when looking at mature astrocytes or microglia in this brain region. These findings may be difficult to interpret given the heterogeneity of ASD. In particular, one problem with interpreting genotypic differences between mouse models of ASD is that the rare mutant variants account for $<1 \%$ of all ASD cases (Devlin and Scherer, 2012). Comparing individuals with these specific abnormalities, similarities reflective of the core symptoms of ASD can be seen; however, differences in severity, seizure prevalence, muscle tone, developmental delay, and other comorbid conditions exist (Devlin and Scherer, 2012; Parikshak et al., 2013). While mouse models based on rare mutations offer useful models to study the development of ASD, there are often difficulties relating behavioral deficits in rodents to those seen in humans (Nestler and Hyman, 2010). These difficulties may be due, in part, to the likelihood that ASD is caused by multiple genetic factors, which together comprise an individual's genetic liability (Geschwind, 2011). Nevertheless, the fact that many of the ASD candidate genes, including Cntnap2 and Shank3, are associated with both neuronal and glial plasticity as well as with synapse development, at least suggests the possibility of shared underlying mechanisms or biomarkers for many, if not all, forms of ASD (Cahoy et al., 2008; Peñagarikano et al., 2011; Jiang and Ehlers, 2013).

Postmortem studies show increased levels of glial markers in the brains of patients with ASD (Vargas et al., 2005; Morgan et al., 2010), and experimental studies have also linked glial dysregulation to ASD. Methyl-CpGbinding protein-2 (MECP2), a transcription factor that is expressed in neurons and glia, is atypically expressed in ASD and mutated in Rett syndrome, which produces many symptoms similar to those in ASD (Ballas et al., 2009; Maezawa et al., 2009). The absence of MECP2 in astrocytes impedes normal neuronal growth (Ballas et al., 2009). On the other hand, re-expression of MECP2 in astrocytes of MECP2-null mice restored these alterations in dendritic morphology and significantly improved Rett syndrome-like behaviors, such as locomotion and anxiety levels (Lioy et al., 2011). Another study (Maezawa and Jin, 2010) showed that knockout of MECP2 specifically in microglial cells causes stunted dendritic growth of hippocampal neurons and damages the postsynaptic elements of excitatory synapses by increasing the release of glutamate. Mice lacking $\mathrm{C} \times 3 \mathrm{Cr} 1$, a chemokine receptor expressed by microglia that is involved in neuron-microglia cross talk, not only have reduced numbers of new neurons (Bachstetter et al., 2011), but they also have an autistic-like behavioral phenotype, including impaired social interaction and increased repetitive behaviors (Zhan et al., 2014). These transgenic mice also exhibit alterations in neural circuitry commonly associated with ASD, 
including impaired synaptic pruning, weak synaptic transmission, and decreased long-range functional connectivity (Paolicelli et al., 2011; Zhan et al., 2014).

Although we did not find common abnormalities in astrocytes or microglia across the two autism mouse models, our findings do not exclude the possibility that astrocytic and microglial dysfunction are important in the etiology of ASD. Indeed, abnormalities in these cell types may have existed early in life that had resolved by adulthood. The mechanisms of ASD are known to have their onset in the first year of human postnatal life, and many ASD genes are coexpressed in mid-gestation in the developing human brain (Willsey et al., 2013). In mice, the mechanisms of neocortical synapse proliferation and elimination are likely to reach a peak in the first 2 months of postnatal life (Alvarez and Sabatini, 2007). Our measurements, which were performed on mice at later ages, would tend to emphasize aberrations in plasticity mechanisms that persisted even after this period has ended. In this regard, it is notable that our positive results were found in the dentate gyrus, a structure that undergoes a considerable amount of neurogenesis and other forms of plasticity throughout adult life. One potential mechanism is that proper synapse formation and elimination does not occur in ASD individuals, producing abnormal neural connectivity. CD68, a microglial lysosomal marker associated with the engulfment of synapses, is present in high quantities in the mouse brain early in development compared with adulthood (Schafer et al., 2012). Since both astrocytes and microglia play a role in shaping neural circuitry by actively engulfing weak synapses during early life (Paolicelli et al., 2011; Schafer et al., 2012; Chung et al., 2013), glial dysfunction leading to ASD may occur at an early age. In our study, we examined 5- to 6-month-old male mice. The adult time point was specifically chosen because most reported autism-like behaviors for these transgenic lines were examined in adult mice (Peñagarikano et al., 2011; Duffney et al., 2015). Thus, future work is needed to determine whether a more consistent and robust alteration in glial cells occurs in mouse models of ASD at younger ages.

It is also possible that astrocyte and microglia abnormalities exist, but are not detectable using our specific measures. Although lba1 is a well known marker of microglia and robustly labels all cells of macrophage origin (Ito et al., 1998), heterogeneity in astrocytic cell populations is an important consideration. Despite the fact that both GFAP and S100 are common markers for astrocytes, these markers only label a relatively small proportion of astrocytes (Cahoy et al., 2008). In fact, not all astrocytes colabel with GFAP and S100 (Cahoy et al., 2008; Brockett et al., 2015), suggesting that there are different subpopulations of astrocytes, which may be differentially altered in ASD. Additionally, GFAP does not label the entirety of astrocytic processes and is largely absent from astrocytic end feet (Bushong et al., 2002), so morphology could be altered in ASD but in regions of the cell that do not label with GFAP. Both microglia and astrocytes are highly dynamic and can change morphologies within a matter of minutes (Nimmerjahn et al., 2005; Theodosis et al., 2008;
Perez-Alvarez et al., 2014). Our findings leave open the possibility that more subtle changes in morphology may occur in ASD as well as in other brain regions that are not explored here but are implicated in ASD (Schumann and Amaral, 2006; Dichter et al., 2012; Wang et al., 2014).

Our findings, along with those of a previous study (Stephenson et al., 2011), suggest that diminished adult neurogenesis in the hippocampus may be a feature shared by many ASD mouse models. Our additional finding of reduced numbers of astroglial cells with radial morphology in the ventral SGZ suggest that decreased numbers of immature neurons occur as a result of fewer progenitor cells. Since radial glial cells serve as neuronal progenitors during development as well as in adulthood, it is possible that these findings reflect residual evidence of a neurogenesis deficit that exists during development in multiple brain regions. Indeed, studies suggest that some of the gross structural abnormalities detected in the postmortem ASD brain may arise from aberrant neurogenesis (Williams and Casanova, 2010). However, the extent to which deficits in radial glial progenitor cells and neurogenesis contribute to symptoms of ASD remains to be determined.

\section{References}

Alvarez VA, Sabatini B (2007) Anatomical and physiological plasticity of dendritic spines. Annu Rev Neurosci 30:79-97. CrossRef Medline

American Psychiatric Association (2013) Diagnostic and statistical manual of mental disorders: DSM-5. Washington, DC: American Psychiatric Association.

Ashwood P, Krakowiak P, Hertz-Picciotto I, Hansen R, Pessah I, Van de Water J (2011) Elevated plasma cytokines in autism spectrum disorders provide evidence of immune dysfunction and are associated with impaired behavioral outcome. Brain Behav Immun 25:40-45. CrossRef Medline

Atladóttir HO, Thorsen $\mathrm{P}$, Østergaard L, Schendel DE, Lemcke S, Abdallah M, Parner ET (2010) Maternal infection requiring hospitalization during pregnancy and autism spectrum disorders. J Autism Dev Disord 40:1423-1430. CrossRef Medline

Bachstetter AD, Morganti JM, Jernberg J, Schlunk A, Mitchell SH, Brewster KW, Hudson CE, Cole MJ, Harrison JK, Bickford PC, Gemma C (2011) Fractalkine and $\mathrm{CX}_{3} \mathrm{CR} 1$ regulate hippocampal neurogenesis in adult and aged rats. Neurobiol Aging 32:20302044. CrossRef Medline

Ballas N, Lioy DT, Grunseich C, Mandel G (2009) Non-cell autonomous influence of MeCP2-deficient glia on neuronal dendritic morphology. Nat Neurosci 12:311-317. CrossRef Medline

Brockett AT, LaMarca EA, Gould E (2015) Physical exercise enhances cognitive flexibility as well as astrocytic and synaptic markers in the medial prefrontal cortex. PLoS One 10:e0124859. CrossRef Medline

Bushong EA, Martone ME, Jones YZ, Ellisman MH (2002) Protoplasmic astrocytes in CA1 stratum radiatum occupy separate anatomical domains. J Neurosci 22:183-192. Medline

Cahoy JD, Emery B, Kaushal A, Foo LC, Zamanian JL, Christopherson KS, Xing Y, Lubischer JL, Krieg PA, Krupenko SA, Thompson WJ, Barres BA (2008) A transcriptome database for astrocytes, neurons and oligodendrocytes: a new resource for understanding brain development and function. J Neurosci 28:264-278. CrossRef Medline

Carper RA, Courchesne E (2005) Localized enlargement of the frontal cortex in early autism. Biol Psychiatry 57:126-133. CrossRef Medline

Christensen DL, Baio J, Braun KV, Bilder D, Charles J, Constantino JN, Daniels J, Durkin MS, Fitzgerald RT, Kurzius-Spencer M, Lee 
LC, Pettygrove S, Robinson C, Schulz E, Wells C, Wingate MS, Zahorodny W, Yeargin-Allsopp M (2012) Prevalence and characteristics of autism spectrum disorder among children aged 8 years - autism and developmental disabilities monitoring network, 11 sites, United States, 2012. MMWR Surveill Summ 65:1-23.

Christopherson KS, Ullian EM, Stokes CC, Mullowney CE, Hell JW, Agah A, Lawler J, Mosher DF, Bornstein P, Barres BA (2005) Thrombospondins are astrocyte-secreted proteins that promote CNS synaptogenesis. Cell 120:421-433. CrossRef Medline

Chung WS, Clarke LE, Wang GX, Stafford BK, Sher A, Chakraborty C, Joung J, Foo LC, Thompson A, Chen C, Smith SJ, Barres BA (2013) Astrocytes mediate synapse elimination through MEGF10 and MERTK pathways. Nature 504:394-400. CrossRef Medline

Devlin B, Scherer SW (2012) Genetic architecture in autism spectrum disorder. Curr Opin Genet Dev 22:229-237. CrossRef Medline

Dichter GS, Felder JN, Green SR, Rittenberg AM, Sasson NJ, Bodfish JW (2012) Reward circuitry function in autism spectrum disorders. Soc Cogn Affect Neurosci 7:160-172. CrossRef Medline

Duffney LJ, Zhong P, Wei J, Matas E, Cheng J, Qin L, Ma K, Dietz DM, Kajiwara Y, Buxbaum JD, Yan Z (2015) Autism-like deficits in Shank3-deficient mice are rescued by targeting actin regulators. Cell Rep 11:1400-1413. CrossRef Medline

Fanselow MS, Dong HW (2010) Are the dorsal and ventral hippocampus functionally distinct structures? Neuron 65:7-19. CrossRef Medline

Franklin KBJ, Paxinos G (2008) The mouse brain in stereotaxic coordinates, Ed 3. New York: Elsevier Science.

Geschwind DH (2011) Genetics of autism spectrum disorder. Trends Cogn Sci 15:409-416. CrossRef Medline

Gdalyahu A, Lazaro M, Penagarikano O, Golshani P, Trachtenberg JT, Geschwind DH (2015) The autism related protein contactinassociated protein-like 2 (CNTNAP2) stabilizes new spines: an in vivo mouse study. PLoS One 10:e0125633. CrossRef

Goh S, Peterson BS (2012) Imaging evidence for disturbances in multiple learning and memory systems in persons with autism spectrum disorders. Dev Med Child Neurol 54:208-213. CrossRef Medline

Henneberger C, Papouin T, Oliet SH, Rusakov DA (2010) Long-term potentiation depends on release of D-serine from astrocytes. Nature 463:232-236. CrossRef Medline

Hutsler JJ, Zhang H (2010) Increased dendritic spine densities on cortical projection neurons in autism spectrum disorders. Brain Res 1309:83-94. CrossRef Medline

Ito D, Imai Y, Ohsawa K, Nakajima K, Fukuuchi Y, Kohsaka S (1998) Microglia-specific localisation of a novel calcium binding protein, Iba1. Brain Res Mol Brain Res 57:1-9. Medline

Jiang YH, Ehlers MD (2013) Modeling autism by SHANK gene mutations in mice. Neuron 78:8-27. CrossRef

Kinney DK, Munir KM, Crowley DJ, Miller AM (2008) Prenatal stress and risk for autism. Neurosci Biobehav Rev 32:1519-1532. CrossRef Medline

Kondo S, Kohsaka S, Okabe S (2011) Long-term changes of spine dynamics and microglia after transient peripheral immune response triggered by LPS in vivo. Mol Brain 4:27CrossRef Medline

Kouser M, Speed HE, Dewey CM, Reimers JM, Widman AJ, Gupta N, Liu S, Jaramillo TC, Bangash M, Xiao B, Worley PF, Powell CM (2013) Loss of predominant Shank3 isoforms results in hippocampus-dependent impairments in behavior and synaptic transmission. J Neurosci 33:18448-18468. CrossRef Medline

Kucukdereli H, Allen NJ, Lee AT, Feng A, Ozlu MI, Conatser LM, Chakraborty C, Workman G, Weaver M, Sage EH, Barres BA, Eroglu C (2011) Control of excitatory CNS synaptogenesis by astrocyte-secreted proteins Hevin and SPARC. Proc Natl Acad Sci U S A 108:E440-E449. CrossRef Medline

Langen M, Schnack HG, Nederveen H, Bos D, Lahuis BE, de Jonge MV, van Engeland H, Durston S (2009) Changes in the development trajectories of striatum in autism. Biol Psychiatry 66:327-333. CrossRef Medline
Lázaro MT, Golshani P (2015) The utility of rodent models of autism spectrum disorder. Curr Opin Neurol 28:103-109. CrossRef Medline

Lioy DT, Garg SK, Monaghan CE, Raber J, Foust KD, Kaspar BK, Hirrlinger PG, Kirchhoff F, Bissonnette JM, Ballas N, Mandel G (2011) A role for glia in the progression of Rett's syndrome. Nature 475:497-500. CrossRef Medline

Lugert S, Basak O, Knuckles P, Haussler U, Fabel K, Götz M, Haas CA, Kempermann G, Taylor V, Giachino C (2010) Quiescent and active hippocampal neural stem cells with distinct morphologies respond selectively to physiological and pathological stimuli and aging. Cell Stem Cell 6:445-456. CrossRef Medline

Maezawa I, Jin LW (2010) Rett syndrome microglia damage dendrites and synapses by the elevated release of glutamate. J Neurosci 30:5346-5356. CrossRef Medline

Maezawa I, Swanberg S, Harvey D, LaSalle JM, Jin LW (2009) Rett syndrome astrocytes are abnormal and spread MeCP2 deficiency through gap junctions. J Neurosci 29:5051-5061. CrossRef Medline

Morgan JT, Chana G, Pardo CA, Achim C, Semendeferi K, Buckwalter J, Courchesne E, Everall IP (2010) Microglial activation and increased microglial density observed in the dorsolateral prefrontal cortex in autism. Biol Psychiatry 68:368-376. CrossRef Medline

Nestler EJ, Hyman SE (2010) Animal models of neuropsychiatric disorders. Nat Neurosci 13:1161-1169. CrossRef Medline

Nimmerjahn A, Kirchhoff F, Helmchen F (2005) Resting microglial cells are highly dynamic surveillants of brain parenchyma in vivo. Science 308:1314-1318. CrossRef Medline

Oberheim NA, Takano T, Han X, He W, Lin JH, Wang F, Xu Q, Wyatt JD, Pilcher W, Ojemann JG, Ransom BR, Goldman SA, Nedergaard M (2009) Uniquely hominid features of adult human astrocytes. J Neurosci 29:3276-3287. CrossRef Medline

Opendak M, Gould E (2015) Adult neurogenesis: a substrate for experience-dependent change. Trends Cogn Sci 19:151-161. CrossRef Medline

Opendak M, Offit L, Monari P, Schoenfeld T, Sonti A, Cameron HA, Gould E (2016) Lasting adaptations in social behavior produced by social disruption and inhibition of adult neurogenesis. J Neurosci 36:7027-7038. CrossRef Medline

Ozonoff S, Young GS, Carter A, Messinger D, Yirmiya N, Zwaigenbaum L, Bryson S, Carver LJ, Constantino JN, Dobkins K, Hutman T, Iverson JM, Landa R, Rogers SJ, Sigman M, Stone WL (2011) Recurrence risk for autism spectrum disorders: a baby siblings research consortium study. Pediatrics 128:e488-e495. CrossRef Medline

Parikshak NN, Luo R, Zhang A, Won H, Lowe JK, Chandran V, Horvath S, Geschwind DH (2013) Integrative functional genomic analyses implicate specific molecular pathways and circuits in autism. Cell 155:1008-1021. CrossRef Medline

Paolicelli RC, Bolasco G, Pagani F, Maggi L, Scianni M, Panzanelli P, Giustetto M, Ferreira TA, Guiducci E, Dumas L, Ragozzino D, Gross CT (2011) Synaptic pruning by microglia is necessary for normal brain development. Science 333:1456-1458. CrossRef Medline

Peñagarikano O, Abrahams BS, Herman El, Winden KD, Gdalyahu A Dong H, Sonnenblick LI, Gruver R, Almajano J, Bragin A, Golshani P, Trachtenberg JT, Peles E, Geschwind DH (2011) Absence of CNTNAP2 leads to epilepsy, neuronal migration abnormalities, and core autism-related deficits. Cell 147:235-246. CrossRef Medline

Penzes P, Cahill ME, Jones KA, VanLeeuwen JE, Woolfrey KM (2011) Dendritic spine pathology in neuropsychiatric disorders. Nat Neurosci 14:285-293. CrossRef Medline

Perez-Alvarez A, Navarrete M, Covelo A, Martin ED, Araque A (2014) Structural and functional plasticity of astrocyte processes and dendritic spine interactions. J Neurosci 34:12738-12744. CrossRef Medline

Rosenberg RE, Law JK, Yenokyan G, McGready J, Kaufmann WE, Law PA (2009) Characteristics and concordance of autism spec- 
trum disorders among 277 twin pairs. Arch Pediatr Adolesc Med 163:907-914. CrossRef Medline

Russell AJ, Murphy CM, Wilson E, Gillan N, Brown C, Robertson DM, Craig MC, Deeley Q, Zinkstok J, Johnston K, McAlonan GM, Spain D, Murphy DG (2016) The mental health of individuals referred for assessment of autism spectrum disorder in adulthood: a clinic report. Autism 20:623-627. CrossRef Medline

Schafer DP, Lehrman EK, Kautzman AG, Koyama R, Mardinly AR, Yamasaki R, Ransohoff RM, Greenberg ME, Barres BA, Stevens B (2012) Microglia sculpt postnatal neural circuits in an activity and complement-dependent manner. Neuron 74:691-705. CrossRef

Schumann CM, Amaral DG (2006) Stereological analysis of amygdala neuron number in autism. J Neurosci 26:7674-7679. CrossRef Medline

Schumann CM, Hamstra J, Goodlin-Jones BL, Lotspeich LJ, Kwon $\mathrm{H}$, Buonocore MH, Lammers CR, Reiss AL, Amaral DG (2004) The amygdala is enlarged in children but not adolescents with autism; the hippocampus is enlarged at all ages. J Neurosci 24:63926401. CrossRef Medline

Simonoff E, Pickles A, Charman T, Chandler S, Loucas T, Baird G (2008) Psychiatric disorders in children with autism spectrum disorders: prevalence, comorbidity, and associated factors in a population-derived sample. J Am Acad Child Adolesc Psychiatry 47:921-929. CrossRef

Stephenson DT, O'Neill SM, Narayan S, Tiwari A, Arnold E, Samaroo HD, Du F, Ring RH, Campbell B, Pletcher M, Vaidya VA, Morton D (2011) Histopathologic characterization of the BTBR mouse model of autistic-like behavior reveals selective changes in neurodevelopmental proteins and adult hippocampal neurogenesis. Mol Autism 2:7. CrossRef Medline

Theodosis DT, Poulain DA, Oliet SH (2008) Activity-dependent structural and functional plasticity of astrocyte-neuron interactions. Physiol Rev 88:983-1008. CrossRef Medline van Steensel FJ, Bögels SM, Perrin S (2011) Anxiety disorders in children and adolescents with autistic spectrum disorders: a metaanalysis. Clin Child Fam Psychol Rev 14:302-317. CrossRef Medline

Vargas DL, Nascimbene C, Krishnan C, Zimmerman AW, Pardo C (2005) Neuroglial activation and neuroinflammation in the brain of patients with autism. Ann Neurol 57:67-81. CrossRef Medline

Vasa RA, Mazurek MO (2015) An update on anxiety in youth with autism spectrum disorders. Curr Opin Psychiatry 28:83-90. CrossRef Medline

Wang SS-H, Kloth AD, Badura A (2014) The cerebellum, sensitive periods, and autism. Neuron 83:518-532. CrossRef Medline

Williams EL, Casanova MF (2010) Autism or autisms? Finding the lowest common denominator. Bol Asoc Med P R 102:17-24. Medline

Willsey AJ, Sanders SJ, Li M, Dong S, Tebbenkamp AT, Muhle RA, Reilly SK, Lin L, Fertuzinhos S, Miller JA, Murtha MT, Bichsel C, Niu W, Cotney J, Ercan-Sencicek AG, Gockley J, Gupta AR, Han W, He X, Hoffman EJ, et al. (2013) Coexpression networks implicate human midfetal deep cortical projection neurons in the pathogenesis of autism. Cell 155:997-1007. CrossRef Medline

Xu N, Li X, Zhong Y (2015) Inflammatory cytokines: potential biomarkers of immunologic dysfunction in autism spectrum disorders. Mediators Inflamm 2015:531518. CrossRef Medline

Zager A, Peron JP, Mennecier G, Rodrigues SC, Aloia TP, PalermoNeto $J$ (2015) Maternal immune activation in late gestation increases neuroinflammation and aggravates experimental autoimmune encephalomyelitis in the offspring. Brain Behav Immun 43:159-171. CrossRef Medline

Zhan Y, Paolicelli RC, Sforazzini F, Weinhard L, Bolasco G, Pagani F, Vyssotski AL, Bifone A, Gozzi A, Ragozzino D, Gross CT (2014) Deficient neuron-microglia signaling results in impaired functional brain connectivity and social behavior. Nat Neurosci 17:400-406. CrossRef Medline 